
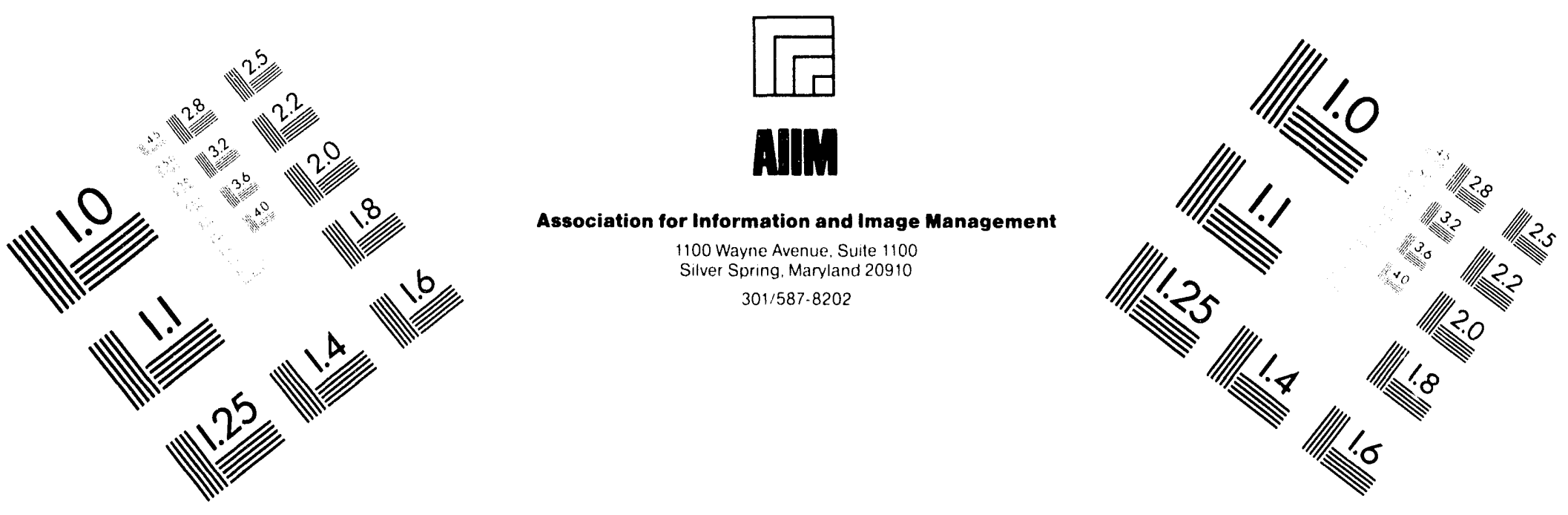

\title{
Centimeter
}

|m Inches
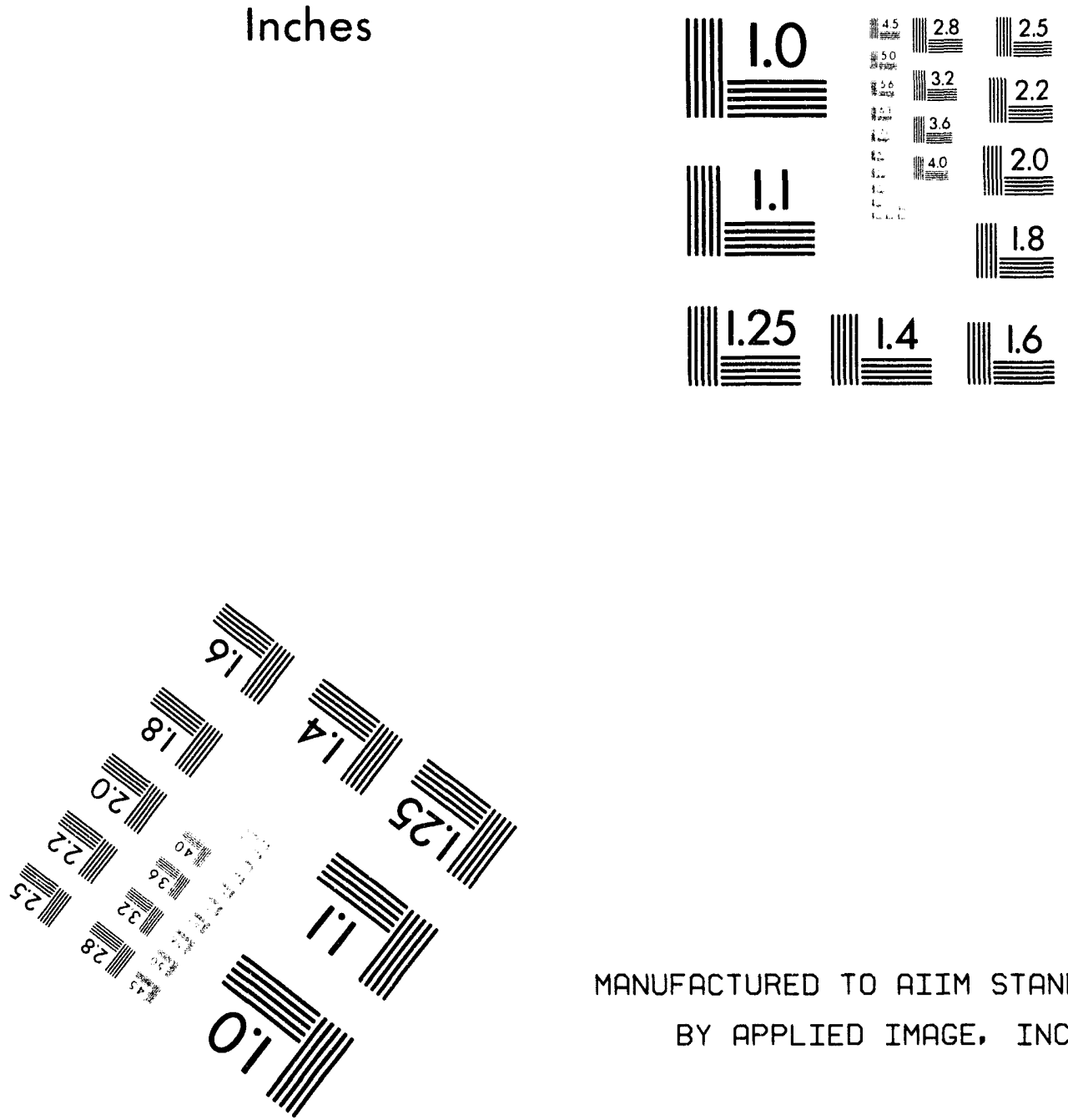

MANUFACTURED TO AIIM STANDARDS

BY APPLIED IMAGE, INC.

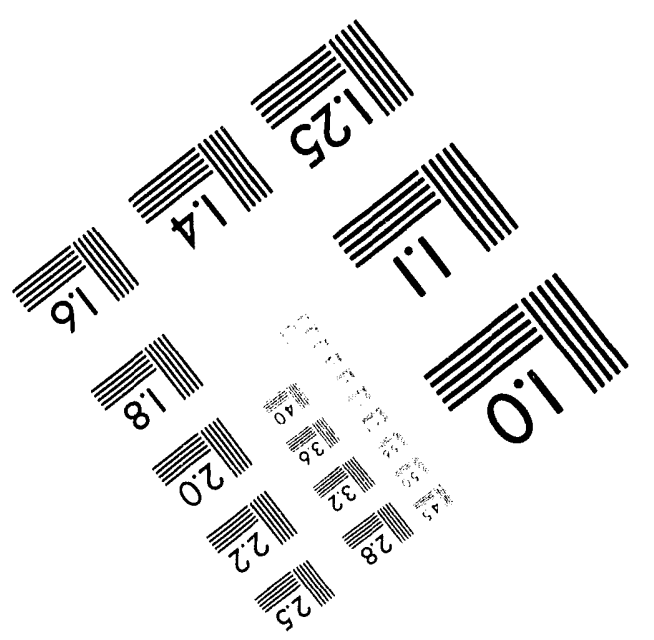



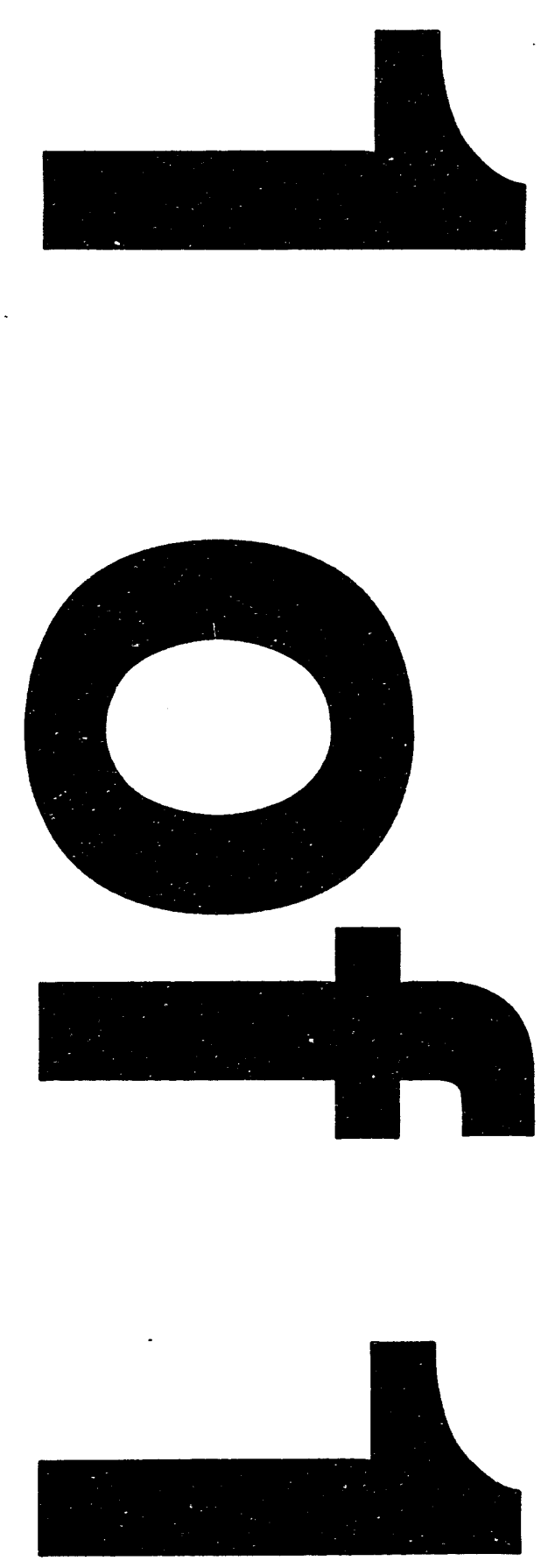


\section{Impact of a 1,000-Foot Thermal Mixing Zone on the Steam Electric Power Industry}

by J.A. Veil

Environmental Assessment Division,

Argonne National Laboratory, 9700 South Cass Avenue, Argonne, Illinois 60439

April 1994

Work sponsored by United States Department of Energy, Assistant Secretary for Policy, Planning, and Program Evaluation, under Contract W-31-109-Eng-38 
This report is printed on recycled paper. 


\section{CONTENTS}

NOTATION $\ldots \ldots \ldots \ldots \ldots \ldots \ldots \ldots \ldots \ldots \ldots \ldots \ldots \ldots \ldots \ldots \ldots$

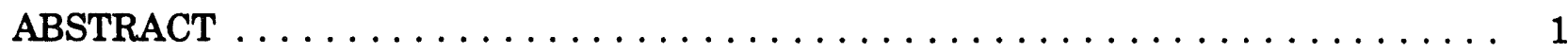

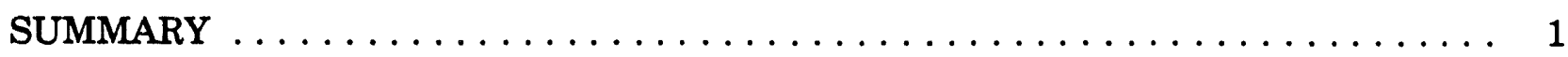

1 INTRODUCTION $\ldots \ldots \ldots \ldots \ldots \ldots \ldots \ldots \ldots \ldots \ldots \ldots \ldots \ldots \ldots$

1.1 Use of Cooling Water in Power Generation $\ldots \ldots \ldots \ldots \ldots \ldots \ldots$

1.2 Overview of Controls on Thermal Discharges $\ldots \ldots \ldots \ldots \ldots$

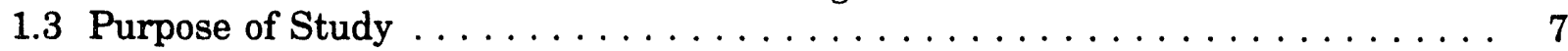

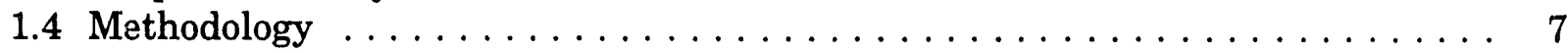

2 AFFECTED FACILITIES $\ldots \ldots \ldots \ldots \ldots \ldots \ldots \ldots \ldots \ldots \ldots$

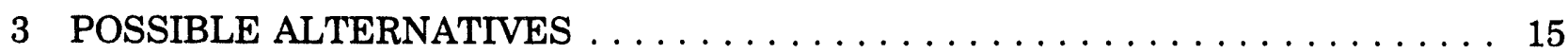

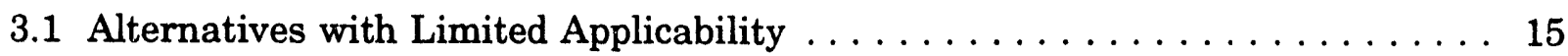

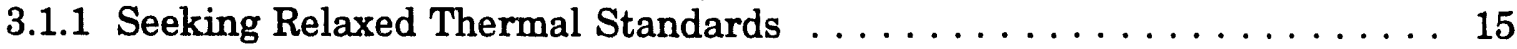

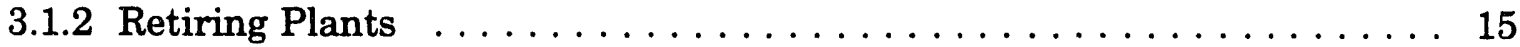

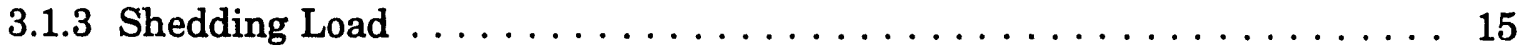

3.1 .4 Using Cooling Ponds or Lakes . . . . . . . . . . . . . . . 16

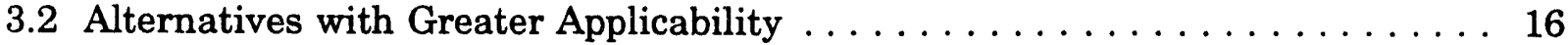

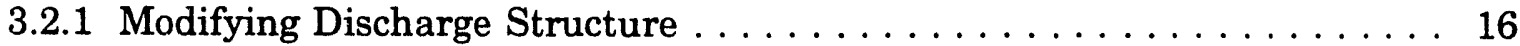

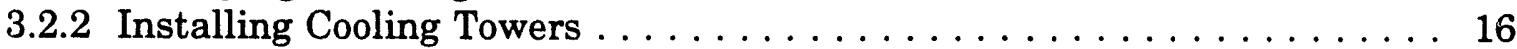

3.3 Alternatives Selected $\ldots \ldots \ldots \ldots \ldots \ldots \ldots \ldots \ldots$

4 CAPITAL COSTS TO COMPLY WITH A 1,000-FOOT MIXING ZONE $\ldots \ldots \ldots$

4.1 Elements of a Capital Cost Estimate $\ldots \ldots \ldots \ldots \ldots \ldots \ldots \ldots \ldots$

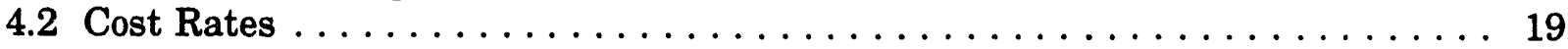

4.2 .1 Cooling Towers $\ldots \ldots \ldots \ldots \ldots \ldots \ldots \ldots \ldots \ldots \ldots \ldots$

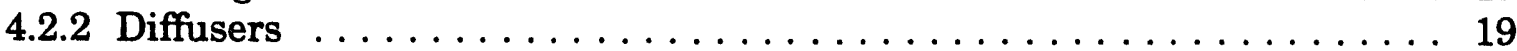

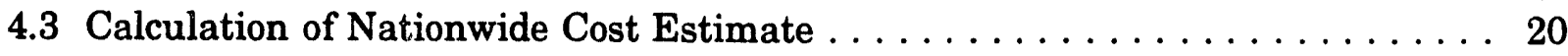

5 ADDITIONAL ENERGY COSTS TO COMPLY WITH A

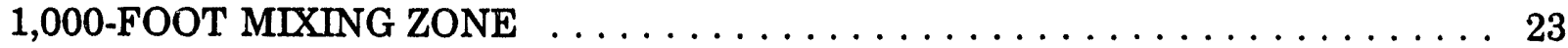

5.1 Description of the Energy Penalty $\ldots \ldots \ldots \ldots \ldots \ldots \ldots \ldots \ldots \ldots \ldots$

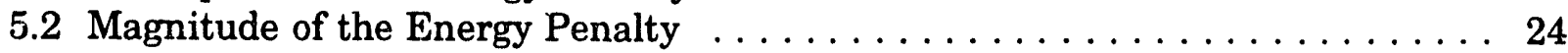

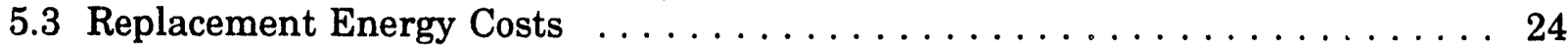

5.3 .1 Cost of Generating Replacement Energy . . . . . . . . . . . . 24

5.3.2 Capital Cost of Building New Generating Capacity . . . . . . . . 25 


\section{CONTENTS (Cont.)}

6 ENVIRONMENTAL IMPACTS OF RETROFITTING COOLING TOWERS

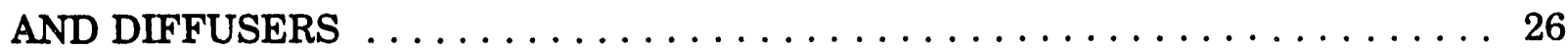

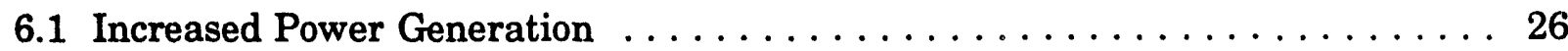

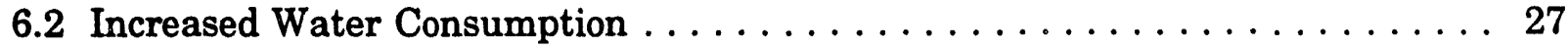

7 FINDINGS AND CONCLUSIONS $\ldots \ldots \ldots \ldots \ldots \ldots \ldots \ldots \ldots \ldots \ldots \ldots \ldots$

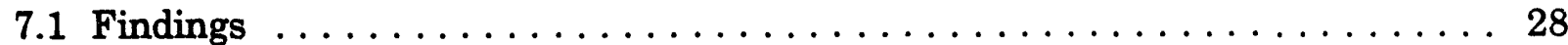

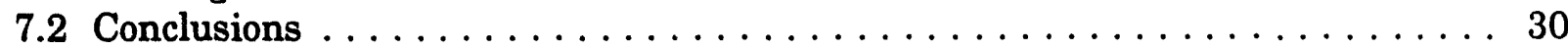

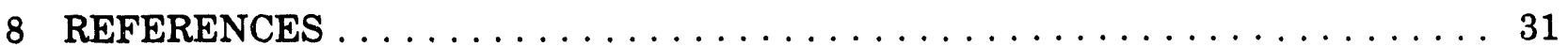

\section{TABLES}

1 Data on the Ability of Sampled Power Plants to Meet a 1,000-Foot Mixing Zone Limit

2 Capital Cost Rates to Retrofit Various Types of Cooling Systems, Based on Data from NERA and Stone \& Webster . . . . . . . . . . . . . . 20

3 Calculation of Nationwide Capital Cost Estimate $\ldots \ldots \ldots \ldots \ldots \ldots \ldots \ldots 22$

4 Nationwide Replacement Energy and Capacity Needed to Compensate for the Energy Penalty Associated with Compliance Alternatives . 


\section{NOTATION}

The following is a list of the abbreviations and acronyms used in this report.

$\begin{array}{ll}\text { CFR } & \text { Code of Federal Regulations } \\ \text { Cir. } & \text { Circuit (Court) } \\ \text { CT } & \text { cooling tower } \\ \text { CWA } & \text { Clean Water Act } \\ \text { DOE } & \text { U.S. Department of Energy } \\ \text { EEI } & \text { Edison Electric Institute } \\ \text { ELG } & \text { effiuent limitation guideline } \\ \text { EPA } & \text { U.S. Environmental Protection Agency } \\ \text { EPRI } & \text { Electric Power Research Institute } \\ \text { kW } & \text { kilowatt(s) } \\ \text { kWh } & \text { kilowatt-hour(s) } \\ \text { MW } & \text { megawatt(s) } \\ \text { NERA } & \text { National Economic Research Associates, Inc. } \\ \text { NPDES } & \text { National Pollutant Discharge Elimination System } \\ \text { O\&M } & \text { operation and maintenance } \\ \text { S. } & \text { Senate Bill } \\ \text { S\&W } & \text { Stone and Webster }\end{array}$




\title{
IMPACT OF A 1,000-FOOT THERMAL MIXING ZONE ON THE STEAM ELECTRIC POWER INDUSTRY
}

by

\author{
J.A. Veil
}

\begin{abstract}
Thermal discharge requirements for power plants using oncethrough cooling systems are based on state water quality standards for temperatures that must be met outside of designated mixing zones. This study evaluates the impact of limiting the extent of thermal mixing zones to no more than 1,000 feet from the discharge point. Data were collected from 79 steam electric plants. Of the plants currently using once-through cooling systems, $74 \%$ could not meet current thermal standards at the edge of a 1,000-foot mixing zone. Of this total, $68 \%$ would retrofit cooling towers, and $6 \%$ would retrofit diffusers. The estimated nationwide capital cost for retrofitting plants that could not meet current thermal standards at the edege of a 1,000 -foot mixing zone is $\$ 21.4$ billion. Conversion of a plant from once-through cooling to cooling towers or addition of diffusers would result in a lower energy output from that plant. Any power company faced with retrofitting a cooling tower or diffuser would have to make up the energy lost. For the affected plants, the total estimated replacement cost would be $\$ 370$ to $\$ 590$ million per year. Over a 20 -year period, the estimated cost would be $\$ 10$ to $\$ 16.2$ billion. Some power companies would have to construct new generating capacity to meet the increased energy demand. The estimated nationwide cost of this additional capacity would be $\$ 1.2$ to $\$ 4.8$ billion. In addition to the direct costs associated with compliance with a 1,000-foot mixing zone limit, other secondary environmental impacts would also occur. Generation of the additional power needed would increase carbon dioxide emissions by an estimated 8.3 million tons per year. In addition, conversion from once-through cooling systems to cooling towers at affected plants would result in increased evaporation of about 2.7 million gallons of water per minute nationwide.
\end{abstract}

\section{SUMMARY}

Across the United States, power plants with a total of more than 250,000 megawatts (MW) of generating capacity use once-through cooling systems. In many cases, thermal discharge requirements for these plants are based on state water quality standards for 
temperatures that must be met outside of designated mixing zones. The methods and criteria used to determine the size and shape of allowable mixing zones differ from state to state. This study was originally undertaken to analyze the effects on the steam electric power industry of Senate Bill 1081 (S. 1081), the 1991 Senate Clean Water Act (CWA) reauthorization bill. Among other provisions, S. 1081 would have limited the extent of mixing zones (thermal and otherwise) to no more than 1,000 feet from the discharge point. The bill would also have repealed Section 316(a) of the CWA, thus eliminating the specific provision allowing variances from thermal limits. Therefore, when the data presented here were gathered, it was assumed that no variances from thermal limits would be available and that mixing zones would be limited to 1,000 feet. However, S. 1081 was not enacted into law.

The most current Senate CWA reauthorization bill, S. 1114, includes neither a repeal of Section 316(a) nor a 1,000-foot limit on mixing zones. Although it remains unclear how Congress intends to deal with thermal issues in reauthorizing the CWA, the impact on the steam electric industry of any provision that would severely constrain the size of mixing zones remains a matter of concern.

This report is based on data collected for 79 steam electric plants, representing 13 power companies in different parts of the country. Although this sample was intended to be representative of the entire steam electric power industry, it is not possible to verify that this goal was achieved.

Data collected from the 79 plants in the sample indicate that $74 \%$ of the plants currently using once-through cooling systems could not meet current thermal standards at the edge of a 1,000-foot mixing zone. Of this total, 68\% would add (retrofit) cooling towers (one of the plants in this group would be retired), and $6 \%$ would retrofit diffusers in order to meet the mixing zone limits. The literature indicates that the capital costs of retrofitting cooling towers are $\$ 108$ per kilowatt $(\$ 108 / \mathrm{kW})$ for fossil-fuel plants and $\$ 201 / \mathrm{kW}$ for nuclear plants. Current capital costs for retrofitting diffusers are estimated at $\$ 43 / \mathrm{kW}$ for fossil-fuel plants and $\$ 59 / \mathrm{kW}$ for nuclear plants. These rates are based on literature values that have been scaled up to reflect more current costs. In 1991, U.S. power plants using once-through cooling systems had a total generating capacity of 250,466 MW. Fossil-fuel plants accounted for $213,700 \mathrm{MW}$ (85\%) of this capacity, and nuclear plants made up $36,766 \mathrm{MW}(15 \%)$. Application of the above capital cost rates and the results from the 79 sampled plants regarding the compliance methods they would use to the nationwide generating capacity that would likely be affected yields an estimated total capital cost of $\$ 21.4$ billion ${ }^{1}$ for retrofitting all plants that could not meet current thermal standards at the edge of a 1,000-foot mixing zone.

A plant converting from once-through cooling to cooling towers would have a lower energy output because of increased turbine back pressure and increased auxiliary power demands. Diffusers would also cause an increase in auxiliary power demand because of an increase in pump head. This differential energy output is known as the "energy penalty."

1 All costs are expressed in 1992 U.S. dollars. 
According to the literature, cooling towers result in an energy penalty for fossil-fuel plants ranging from 1.1 to $4.6 \%$ of capacity, with most of the data falling in the range of 1.5 to $2.5 \%$. The cooling tower energy penalty for nuclear plants ranges from 1.0 to $5.8 \%$, with the most relevant data in the range of 2 to $3 \%$. The energy penalty of diffusers is $0.02 \%$ for fossil-fuel plants and $0.028 \%$ for nuclear plants.

Any power company faced with a cooling tower retrofit would have to make up the energy lost as a result of the energy penalty. If the lower values described for the energy penalty $r$ inges are used, between 12.7 and 20.6 billion kilowatt-hours $(\mathrm{kWh})$ per year would have to ive replaced. At an average replacement cost of $29.0 \mathrm{mills} / \mathrm{kWh}$, the estimated nationwide cost of replacement generation would range from $\$ 370$ to $\$ 590$ million per year. Over a 20-year period, the estimated cost would be $\$ 10$ to $\$ 16.2$ billion, assuming zero real escalation in fuel and variable operating and maintenance (O\&M) costs, a discount rate of $10.5 \%$, and an annual inflation rate of $4 \%$. In addition to paying the fuel costs for providing the extra energy, some power companies would have to construct new generating capacity. Nationwide, the cost for this additional capacity is estimated to be from $\$ 1.2$ to $\$ 4.8$ billion.

In summary, the total national cost of restricting thermal mixing zones to 1,000 feet (excluding O\&M costs, which are assumed to be small, and the cost of land acquisition, which is highly variable and site specific) is estimated to be $\$ 22.6$ to $\$ 26.2$ billion in capital costs and $\$ 10$ to $\$ 16.2$ billion in additional energy generation costs over a 20 -year period. In addition to the direct costs that would be incurred with a 1,000-foot mixing zone limit, other secondary environmental impacts would result. The need to generate additional energy would increase carbon dioxide emissions by an estimated 8.3 million tons per year. Construction of new generating units would cause increased solid waste production and environmental impacts such as changes in land use, runoff characteristics, and wildlife habitat. For all affected plants combined, conversion from once-through cooling systems to cooling towers would result in increased evaporation of about 2.7 million gallons of water per minute nationwide. 


\section{INTRODUCTION}

\subsection{USE OF COOLING WATER IN POWER GENERATION}

In many industries, including the steam electric power generating industry, water is used to cool machinery or condense steam. At nuclear and fossil-fuel power plants, electricity is generated by heating purified water to create steam. The steam is used to drive turbines, which in turn drive the generators that produce electricity. After leaving the turbines, the steam passes through a condenser, which serves to transfer heat from the hot steam to the cool water. The condenser contains numerous tubes that create a large surface area for heat transfer. A large volume of cooling water circulates through the tubes, absorbing heat from the steam, which independently circulates around the outside of the tubes. While passing through the condenser, the steam cools and condenses, which raises the temperature of the cooling water as the heat is exchanged from the steam to the cooling water. The condensers are designed to produce a vacuum at the outlet end of the turbine, which increases the efficiency of the system - the lower the initial temperature of the cooling water, the larger the vacuum and the greater the efficiency.

Most power plants use either once-through cooling or closed-cycle cooling. Oncethrough cooling systems withdraw large volumes of water from a river, lake, estuary, or ocean; pump the water through the condenser; and return it to the same or a nearby body of water. Closed-cycle cooling systems ${ }^{2}$ use a cooling tower and basin or a facility-specific cooling pond or cooling lake. In a closed-cycle cooling system with a cooling tower, water is withdrawn from the basin or other water source, pumped to the condenser, and then returned either to the cooling tower or to the basin or other water source. In a cooling tower, the most common type of closed-cycle cooling system, warm water comes in contact with air, and through a heat-exchange process, heat and moisture are transferred to the air and the water is cooled. Since some water evaporates in this process, the concentrations of certain constituents increase in closed-cycle systems. To maintain proper concentrations, a portion of the recirculated water is discharged as blowdown, and fresh water is added.

\subsection{OVERVIEW OF CONTROLS ON THERMAL DISCHARGES}

During the 1970s, thermal discharge issues were considered very important because of concerns about the effects of heat on aquatic life. The first major effort to control thermal discharges was contained in the 1972 amendments to the Federal Water Poilution Control Act, also known as the Clean Water Act (CWA). The CWA classifies heat as a pollutant, and permit limits can be based on either heat or temperature.

The CWA directs the U.S. Environmental Protection Agency (EPA) to publish effluent limitation guidelines (ELGs) that establish national minimum technology-based

2 In this report, the term "closed-cycle cooling" is meant to indicate use of a cooling tower unless some other type of closed cooling system is specifically mentioned. 
discharge standards for many industrial categories. The EPA set ELGs for the steam electric power industry on October 8, 1974 ( 39 Federal Register 36186; 40 CFR Part 423). The ELGs included a prohibition on discharges of heat from the main condensers of power plants. A group of electric utilities sued EPA over a variety of thermal issues, including the heat discharge prohibition. The court set aside the effluent limitation guidelines for heat (Appalachian Power Co. v. Train, 545 F. 2d 1351 [4th Cir., 1976]). The EPA has never adopted any other national technology-based effluent limits on heat or temperature. However, some states have developed their own thermal discharge regulations.

The CWA also directs states to develop water quality standards. Most states have water quality standards that specify the temperature that must not be exceeded outside of designated mixing zones (areas surrounding a discharge point in which the effluent mixes with the receiving water). The methods and criteria used to determine the size and shape of allowable mixing zones differ from state to state. Some states use dimensional criteria, such as "1,000 feet radially from the point of discharge" or "no more than $25 \%$ of the crosssectional width of a stream," while other states rely on case-by-case determination of thermal mixing zones. Typically, large thermal dischargers are required to demonstrate the extent of their thermal plumes through hydrothermal modeling and actual field monitoring. If a permit writer is satisfied that the discharge can meet state thermal standards at the edge of the designated mixing zone, the discharge will be authorized in a National Pollutant Discharge Elimination System (NPDES) permit.

A variance from water-quality-based thermal limits set by EPA and the states is authorized under Section 316(a) of the CWA. Under that provision, the states or EPA can establish alternative thermal limits if the discharger can demonstrate that the otherwise applicable thermal effluent limits are more stringent than necessary to protect the organisms in and on the receiving water body, and that other, less stringent effluent limitations would protect those organisms. The variance does not eliminate the need to meet any applicable water-quality-based linits for constituents of cooling water other than heat or temperature.

Power companies have spent millions of dollars in identifying the size and shape of thermal plumes and demonstrating that the requirements of Section 316(a) are met at their generating stations. One direct benefit of the hundreds of studies is that knowledge of ecosystem dynamics and of the life histories, abundance, and distribution of aquatic organisms has been advanced substantially. As information has accumulated from these studies, it has become generally recognized that thermal impacts on biota are less significant than originally thought. The legislative and regulatory focus on water pollution control has shifted from thermal issues to control of toxic materials and nutrients. In May 1991, U.S. Senators Baucus and Chafee introduced Senate Bill 1081 (S. 1081), a major CWA reauthorization bill, which contained language deleting Section 316(a) and limiting the extent of mixing zones to no more than 1,000 feet from the discharge point (U.S. Senate 1991a). In December 1991, Senate staff members released an updated version of S. 1081 (U.S. Senate 1991b). The revised bill maintained the deletion of the Section 316(a) variance and also prohibited mixing zones (with some exceptions) for most pollutants, including temperature and heat. 
Although the mixing zone limitation in S. 1081 would have applied both to thermal and nonthermal mixing zones, anecdotal evidence suggests that the authors were concerned primarily with nonthermal discharges, particularly discharges of toxic materials. Nevertheless, the bill would have had a significant impact on the steam electric power industry with its multi-million-gallon-per-day cooling water flows. Senate Bill 1081 was not enacted; it lapsed with the end of the 102nd Congress in 1992.

\subsection{PURPOSE OF STUDY}

Power companies often rely on thermal mixing zones or the Section 316(a) variance in siting and operating their plants if they use once-through cooling. Recent reports indicate that deletion of the Section 316(a) variance would cost the power industry an estimated \$22.7-\$24.4 billion in capital costs for retrofitting cooling towers and an estimated additional energy cost of $\$ 12.8-\$ 23.7$ billion for operating the cooling towers over 20 years (Veil 1993; Veil et al. 1993). This study estimates the cost to the power industry if an amendment limiting thermal mixing zones to 1,000 feet from the point of discharge were also enacted.

The most recent version of the Senate CWA reauthorization bill, S. 1114, does not include either a 1,000-foot mixing zone limit or a repeal of Section 316(a) (U.S. Senate 1994). However, an earlier version of S. 1114 (U.S. Senate 1993) would have limited mixing zones to an area "as small as possible" and would have prohibited them in bodies of water classified as "outstanding national resource waters."3 It is unclear whether any mixing zone restrictions will actually be enacted into law. However, because limits on mixing zones have again been proposed and because the data estimating power industry costs to meet a 1,000 -foot mixing zone limit have been collected, those data are analyzed in this report.

This study does not attempt to estimate the impact of a 1,000-foot mixing zone on nonthermal pollutants. Thermal discharges often contain other pollutants for which water quality standards may not always be met within 1,000 feet. Many other industrial and municipal discharges may also contain concentrations of pollutants that fail to meet water quality standards beyond 1,000-foot mixing zones.

\subsection{METHODOLOGY}

The best way to generate a precise cost estimate for nationwide compliance with mixing zone restrictions would be to conduct a detailed cost analysis for every plant in the United States that would be affected. However, most utilities have not invested that level

3 The May 1993 version of S. 1114 specified that, ". . . outstanding national resource waters shall include all waters within a national park, wildlife refuge, wild and scenic river system, national forest, wilderness area, national seashore or lakeshore, or national monument. The State shall also designate as outstanding national resource waters those waters of exceptional recreational, cultural, or ecological significance, including any water that supports a population of threatened or endangered species." 
of effort at this early stage. Therefore, in order to approximate costs for this study, information was collected from a sample of power plants (in different parts of the country) that use once-through cooling. While geographical diversity was sought and achieved, this sample of the steam electric power industry was not designed to be statistically random. Therefore, the results of this study are not necessarily representative of the entire industry. On the other hand, there is no reason to believe that the cost estimates developed in this manner are not a reasonably good gauge of the actual costs to the industry of complying with a 1,000-foot mixing zone limitation.

Responses were received from 13 companies providing the following types of information for 79 plants:

- Name of generating unit and megawatt rating,

- Fuel type,

- Whether the unit operates under a Section 316(a) variance,

- Whether the discharge would meet thermal requirements within 1,000 feet of the discharge point,

- What alternative would be selected if the discharge could not meet thermal requirements within 1,000 feet, and

- Estimated capital cost to implement the alternative.

To estimate nationwide costs, these data were scaled up by using literature values for capital costs of installing equipment necessary for compliance and for costs of providing the additional energy necessary to operate such equipment. This methodology assumes that the limited sample of plants providing data is representative of the nationwide power industry. 


\section{AFFECTED FACILITIES}

To estimate the cost to the U.S. power industry if mixing zones were limited to 1,000 feet, it was first necessary to determine how many plants and how much generating capacity would be affected. Most power plants constructed in this country since the mid-1970s have relied on cooling towers, but many older generating units still use oncethrough cooling and could therefore be affected by such a mixing zone limitation. These plants are located throughout the country.

In 1991, the steam electric generating capacity in the United States totaled $568,871 \mathrm{MW}$. Generating units with $250,466 \mathrm{MW}(44 \%)$ of this capacity used once-through cooling (Edison Electric Institute [EEI] 1993). Many of these units currently operate under a Section 316(a) variance and thus might not be subject to restrictions on mixing zone size. However, because provisions of S. 1081 would have ended Section 316(a) variances in addition to limiting mixing zone size, the power companies were asked to assume for purposes of this study that the mixing zone restrictions would supersede relaxed thermal requirements available under the variance. Consequently, the national cost estimates developed in this report assume that all units with once-through cooling are potentially affected by the provisions of S. 1081 .

Several power companies suggested that the blowdown discharges from some of their lants using cooling towers could not meet applicable thermal requirements at the edge of a 1,000-foot mixing zone (Loudermilk 1993; Wieland 1993; Walton 1993). However, the number of plants using closed-cycle cooling that would be affected by a 1,000-foot mixing zone and the cost of compliance are not estimated in this study.

The data collected from the 13 power companies are summarized in Table 1 . The responses indicated that 24 of the 79 plants for which data were provided may already be able to meet thermal standards at the edge of a 1,000-foot mixing zone. These plants represent $20,085 \mathrm{MW}$ of capacity, which is $26 \%$ of the total capacity reported in the study. Most of the plants in this category either discharge through diffusers or otherwise can meet the applicable thermal discharge standards. However, four of the plants (representing 2,673 MW) are located in Wisconsin, which does not now have any thermal water quality standards. Therefore, these four plants are reported as being able to meet thermal standards at the edge of a 1,000-foot mixing zone. Wisconsin is currently considering establishing a thermal standard, with $89^{\circ} \mathrm{F}$ being the likely standard. None of these four plants could meet an $89^{\circ} \mathrm{F}$ standard with a 1,000 -foot mixing zone. The cost estimates calculated in this report do not include any retrofit costs for the four Wisconsin plants, although some future costs are likely. 
TABLE 1 Data on the Ability of Sampled Power Plants to Meet a 1,000-Foot Mixing Zone Limit

\begin{tabular}{|c|c|c|c|c|c|c|c|}
\hline $\begin{array}{c}\text { Company Name } \\
\text { (reference) }\end{array}$ & Plant & $\begin{array}{c}\text { Capacity } \\
(\mathrm{MW})^{\mathrm{b}}\end{array}$ & Fuel Type & $\begin{array}{l}\text { 316(a) Var. } \\
\text { (Y/N) }\end{array}$ & $\begin{array}{l}\text { Meet 1,000-ft } \\
\text { Mixing Zone } \\
\text { (Y/N) }\end{array}$ & $\begin{array}{c}\text { Alternative Selected } \\
\text { to Meet Mixing } \\
\text { Zone }^{\mathbf{c}} \\
\end{array}$ & $\begin{array}{c}\text { Cost } \\
\text { (million \$) }\end{array}$ \\
\hline $\begin{array}{l}\text { New England Power } \\
\text { (DeHart 1993) }\end{array}$ & $\begin{array}{l}\text { Brayton Point } \\
\text { Salem Harbor } \\
\text { Manchester }\end{array}$ & $\begin{array}{r}1,496 \\
702 \\
128\end{array}$ & $\begin{array}{l}\text { Coal/oil/gas } \\
\text { Coal/oil } \\
\text { Oil/gas }\end{array}$ & $\begin{array}{l}\mathbf{Y} \\
\mathbf{N} \\
\mathbf{Y}\end{array}$ & $\begin{array}{l}\mathbf{N} \\
\mathbf{N} \\
\mathbf{N}\end{array}$ & $\begin{array}{l}\text { CT } \\
\text { CT } \\
\text { CT }\end{array}$ & $\begin{array}{r}110 \\
64 \\
6\end{array}$ \\
\hline $\begin{array}{l}\text { Metropolitan Edison } \\
\text { (Kunkel 1993) }\end{array}$ & Portland & 401 & Coal & $\mathbf{N}$ & $\mathbf{N}$ & CT & $42^{d}$ \\
\hline $\begin{array}{l}\text { Baltimore Gas \& Electric } \\
\text { (Wieland 1993) }\end{array}$ & $\begin{array}{l}\text { Calvert Cliffs } \\
\text { Crane } \\
\text { Gould Street } \\
\text { Wagner } \\
\text { Riverside }\end{array}$ & $\begin{array}{r}1,829 \\
399 \\
103 \\
1,043 \\
333\end{array}$ & $\begin{array}{l}\text { Nuclear } \\
\text { Coal } \\
\text { Oil } \\
\text { Oil/gas/coal } \\
\text { Oil/gas }\end{array}$ & $\begin{array}{l}\mathrm{N} \\
\mathrm{Y} \\
\mathrm{N} \\
? \\
?\end{array}$ & $\begin{array}{l}\mathbf{N} \\
\mathbf{N} \\
\mathbf{N} \\
\mathbf{N} \\
\mathbf{N}\end{array}$ & $\begin{array}{l}\text { CT } \\
\text { CT } \\
\text { CT } \\
\text { CT } \\
\text { CT }\end{array}$ & $\begin{array}{r}368^{\mathrm{d}} \\
43^{\mathrm{d}} \\
11^{\mathrm{d}} \\
113^{\mathrm{d}} \\
8^{\mathrm{d}}\end{array}$ \\
\hline $\begin{array}{l}\text { Potomac Electric Power } \\
\text { Company (Loos 1993; } \\
\text { Bollinger and Bozek 1993) }\end{array}$ & $\begin{array}{l}\text { Dickerson } \\
\text { Chalk Point } \\
\text { Morgantown } \\
\text { Potol. "r. River }\end{array}$ & $\begin{array}{r}570 \\
710 \\
1,206 \\
508\end{array}$ & $\begin{array}{l}\text { Coal } \\
\text { Coal } \\
\text { Coal } \\
\text { Coal }\end{array}$ & $\begin{array}{l}\mathbf{Y} \\
\mathbf{Y} \\
\mathbf{N} \\
\mathbf{N}\end{array}$ & $\begin{array}{l}\mathbf{N} \\
\mathbf{N} \\
\mathbf{N} \\
\mathrm{N}\end{array}$ & $\begin{array}{l}\text { CT } \\
\text { CT } \\
\text { CT } \\
\text { Plant closure }\end{array}$ & $\begin{array}{l}62^{\mathrm{d}} \\
247^{\mathrm{e}} \\
130^{\mathrm{d}} \\
916^{\mathrm{f}}\end{array}$ \\
\hline $\begin{array}{l}\text { Virginia Power (Marshall } \\
\text { 1993) }\end{array}$ & $\begin{array}{l}\text { Bremo } \\
\text { Chesapeake } \\
\text { Chesterfield } \\
\text { Mt. Storm } \\
\text { North Anna } \\
\text { Possum Point } \\
\text { Surry } \\
\text { Yorktown }\end{array}$ & \begin{tabular}{r|}
242 \\
630 \\
1,703 \\
1,654 \\
1,916 \\
487 \\
1,640 \\
1,218
\end{tabular} & $\begin{array}{l}\text { Coal } \\
\text { Coal } \\
\text { Coal/oil/gas } \\
\text { Coal } \\
\text { Nuclear } \\
\text { Oil/coal } \\
\text { Nuclear } \\
\text { Coal/oil/gas }\end{array}$ & $\begin{array}{l}\mathbf{N} \\
\mathbf{N} \\
\mathbf{N} \\
\mathbf{N} \\
\mathbf{Y} \\
\mathbf{N} \\
\mathbf{Y} \\
\mathbf{N}\end{array}$ & $\begin{array}{l}\mathbf{N} \\
\mathbf{N} \\
\mathbf{N} \\
\mathbf{N} \\
\mathbf{Y} \\
\mathbf{N} \\
\mathbf{N} \\
\mathbf{Y}\end{array}$ & $\begin{array}{l}\text { CT } \\
\text { CT } \\
\text { CT } \\
\text { CT } \\
\text { N/A } \\
\text { CT } \\
\text { CT } \\
\text { N/A }\end{array}$ & $\begin{array}{r}26^{\mathrm{d}} \\
68^{\mathrm{d}} \\
184^{\mathrm{d}} \\
179^{\mathrm{d}} \\
\overline{53^{\mathrm{d}}} \\
330^{\mathrm{d}} \\
-\end{array}$ \\
\hline $\begin{array}{l}\text { Carolina Power \& Light } \\
\text { (Oliver 1993) }\end{array}$ & $\begin{array}{l}\text { Asheville } \\
\text { Brunswick } \\
\text { Cape Fear } \\
\text { H.B. Robinson } \\
\text { Roxboro }\end{array}$ & $\begin{array}{r}392 \\
1,521 \\
316 \\
857 \\
1,762\end{array}$ & $\begin{array}{l}\text { Coal } \\
\text { Nuclear } \\
\text { Coal } \\
\text { Coal } \\
\text { Coal }\end{array}$ & $\begin{array}{l}\mathrm{Y} \\
\mathrm{N} \\
\mathrm{N} \\
\mathrm{Y} \\
\mathrm{N}\end{array}$ & $\begin{array}{l}\mathrm{N} \\
\mathrm{Y} \\
\mathrm{Y} \\
\mathrm{N} \\
\mathrm{N}\end{array}$ & $\begin{array}{l}\text { CT or spray system } \\
\text { N/A } \\
\text { N/A } \\
\text { CT or spray system } \\
\text { CT or spray system }\end{array}$ & $\begin{array}{r}42^{\mathrm{d}} \\
\overline{-} \\
93^{\mathrm{d}} \\
190^{\mathrm{d}}\end{array}$ \\
\hline
\end{tabular}


TABLE 1 (Cont.)

\begin{tabular}{|c|c|c|c|c|c|c|c|}
\hline $\begin{array}{c}\text { Company Name } \\
\text { (reference) }\end{array}$ & Plant & $\begin{array}{l}\text { Capacity } \\
(\mathbf{M W})^{\mathrm{b}}\end{array}$ & Fuel Type & $\begin{array}{c}\text { 316(a) Var. } \\
(\mathrm{Y} / \mathrm{N})\end{array}$ & $\begin{array}{l}\text { Meet 1,000-ft } \\
\text { Mixing Zone } \\
\text { (Y/N) }\end{array}$ & $\begin{array}{c}\text { Alternative Selected } \\
\text { to Meet Mixing } \\
\text { Zone }^{c}\end{array}$ & $\begin{array}{c}\text { Cost } \\
\text { (million \$) }\end{array}$ \\
\hline Tennessee Valley & Allen & 800 & Coal & $\mathbf{N}$ & $\mathbf{Y}$ & N/A & - \\
\hline Authority (Loudermilk & Bull Run & 900 & Coal & $\mathbf{Y}$ & $\mathbf{N}$ & Diffuser & $39^{d}$ \\
\hline \multirow[t]{11}{*}{ 1993) } & Browns Ferry & 3,456 & Nuclear & $\mathbf{Y}$ & $\mathbf{N}$ & CT/diffuser & $54^{\mathrm{e}}$ \\
\hline & Colbert & 1,300 & Coal & $\mathbf{Y}$ & $\mathbf{N}$ & CT/diffuser & $148^{\mathrm{e}}$ \\
\hline & Cumberland & 2,600 & Coal & $\mathbf{Y}$ & $\mathbf{N}$ & CT/diffuser & $271^{\mathrm{e}}$ \\
\hline & Gallatin & 1,088 & Coal & $\mathbf{Y}$ & $\mathbf{N}$ & CT/diffuser & $133^{e}$ \\
\hline & John Sevier & 760 & Coal & $?$ & $\mathbf{N}$ & CT & $99^{\mathrm{e}}$ \\
\hline & Johnsonville & 1,336 & Coal & $\mathbf{Y}$ & $\mathbf{N}$ & CTIdiffuser & $162^{e}$ \\
\hline & Kingston & 1,543 & Coal & $\mathrm{Y}$ & $\mathbf{N}$ & CT\diffuser & $168^{\mathrm{e}}$ \\
\hline & Paradise & 2,400 & Coal & $\mathbf{N}$ & $\mathbf{N}$ & Full-time use of CT & $10^{g}$ \\
\hline & Sequoyah & 2,441 & Nuclear & $?$ & $\mathbf{N}$ & Full-time use of CT & $10^{\mathrm{e}}$ \\
\hline & Shawnee & 1,495 & Coal & $\mathbf{N}$ & $\mathbf{N}$ & CT/diffuser & $161^{d}$ \\
\hline & Widows Creek & 1,725 & Coal & $\mathbf{Y}$ & $\mathbf{N}$ & CT/diffuser & $204^{\mathrm{e}}$ \\
\hline \multirow{5}{*}{$\begin{array}{l}\text { PSI Energy } \\
\text { (Nispel 1993) }\end{array}$} & Cayuga & 1,070 & Coal & $\mathbf{Y}$ & $\mathbf{N}$ & CT & $116^{\mathrm{d}}$ \\
\hline & Edwardsport & 176 & Oil/coal & $\mathbf{Y}$ & $\mathbf{N}$ & CT & $19^{d}$ \\
\hline & Gallagher & 628 & Coal & $\mathbf{Y}$ & $\mathbf{N}$ & CT & $68^{d}$ \\
\hline & Noblesville & 111 & Coal & $\mathbf{Y}$ & $\mathbf{N}$ & CT & $12^{\mathrm{d}}$ \\
\hline & Wabash & 871 & Coal & $\mathbf{Y}$ & $\mathbf{N}$ & CT & $94^{\mathrm{d}}$ \\
\hline \multirow{11}{*}{$\begin{array}{l}\text { American Electric Power } \\
\text { (Gaulke 1993) }\end{array}$} & Breed & 325 & Coal & $\mathbf{N}$ & $\mathbf{N}$ & $\mathrm{CT}$ & $35^{d}$ \\
\hline & Cardinal & 1,200 & Coal & $\mathbf{Y}$ & $\mathbf{N}$ & CT & $48^{e}$ \\
\hline & Conesville & 415 & Coal & $\mathbf{N}$ & $\mathbf{N}$ & CT & $22^{\mathrm{e}}$ \\
\hline & Cook & 2,110 & Nuclear & $\mathbf{Y}$ & $\mathbf{N}$ & CT & $485^{\mathrm{e}}$ \\
\hline & Glen Lyn & 335 & Coal & $\mathbf{Y}$ & $\mathbf{N}$ & CT & $36^{\mathrm{d}}$ \\
\hline & Kammer & 630 & Coal & $\mathbf{Y}$ & $\mathbf{N}$ & CT & $65^{e}$ \\
\hline & Kanawha & 400 & Coal & $\mathbf{Y}$ & $\mathbf{N}$ & CT & $30^{e}$ \\
\hline & Muskingum River & 840 & Coal & $\mathbf{N}$ & $\mathbf{N}$ & $\mathrm{CT}$ & $69^{e}$ \\
\hline & Sporn & 1,050 & Coal & $\mathbf{Y}$ & $\mathrm{N}$ & $\mathrm{CT}$ & $87^{e}$ \\
\hline & Picway & 100 & Coal & $\mathbf{Y}$ & $\mathbf{N}$ & CT & $6^{e}$ \\
\hline & Tanners Creek & 995 & Coal & $\mathbf{Y}$ & $\mathrm{N}$ & $\mathrm{CT}$ & $72^{\mathrm{e}}$ \\
\hline
\end{tabular}


TABLE 1 (Cont.)

\begin{tabular}{|c|c|c|c|c|c|c|c|}
\hline $\begin{array}{c}\text { Company Name } \\
\text { (reference) }\end{array}$ & Plant & $\begin{array}{l}\text { Capacity } \\
(\mathbf{M W})^{\mathbf{b}}\end{array}$ & Fuel Type & $\begin{array}{l}\text { 316(a) Var. } \\
\text { (Y/N) }\end{array}$ & $\begin{array}{l}\text { Meet 1,000-ft } \\
\text { Mixing Zone } \\
(\mathrm{Y} / \mathrm{N})\end{array}$ & $\begin{array}{c}\text { Alternative Selected } \\
\text { to Meet Mixing } \\
\text { Zone }^{c}\end{array}$ & $\begin{array}{c}\text { Cost } \\
\text { (million \$) }\end{array}$ \\
\hline $\begin{array}{l}\text { Commonwealth Edison } \\
\text { (Smith 1993; Bollinger } \\
\text { and Bozek 1993) }\end{array}$ & $\begin{array}{l}\text { Quad Cities } \\
\text { Zion } \\
\text { Crawford } \\
\text { Fisk } \\
\text { Joliet } \\
\text { State Line } \\
\text { Waukegan } \\
\text { Will }\end{array}$ & $\begin{array}{r}1,183 \\
2,080 \\
542 \\
321 \\
1,327 \\
490 \\
725 \\
1,092\end{array}$ & $\begin{array}{l}\text { Nuclear } \\
\text { Nuclear } \\
\text { Coal } \\
\text { Coal } \\
\text { Coal } \\
\text { Coal } \\
\text { Coal } \\
\text { Coal }\end{array}$ & $\begin{array}{l}\mathbf{Y} \\
\mathbf{Y} \\
\mathbf{N} \\
\mathbf{N} \\
\mathbf{N} \\
\mathbf{Y} \\
\mathbf{Y} \\
\mathbf{N}\end{array}$ & $\begin{array}{l}\mathbf{Y} \\
\mathbf{N} \\
\mathbf{Y} \\
\mathbf{Y} \\
\mathbf{Y} \\
\mathbf{N} \\
\mathbf{N} \\
\mathbf{Y}\end{array}$ & $\begin{array}{l}\text { N/A } \\
\text { Diffuser or CT } \\
\text { N/A } \\
\text { N/A } \\
\text { N/A } \\
\text { Diffuser or CT } \\
\text { Diffuser or CT } \\
\text { N/A }\end{array}$ & $\begin{array}{r}123^{\mathrm{d}} \\
- \\
- \\
21^{\mathrm{d}} \\
31^{\mathrm{d}} \\
-\end{array}$ \\
\hline $\begin{array}{l}\text { Wisconsin Electric Power } \\
\text { (Michaud 1993; Bollinger } \\
\text { and Bozek 1993) }\end{array}$ & $\begin{array}{l}\text { Oak Creek } \\
\text { Point Beach } \\
\text { Valley Plant } \\
\text { Presque Isle (1-4) } \\
\text { Presque Isle (5-9) } \\
\text { Port Washington }\end{array}$ & $\begin{array}{r}1,112 \\
991 \\
250 \\
177 \\
417 \\
320\end{array}$ & $\begin{array}{l}\text { Coal } \\
\text { Nuclear } \\
\text { Coal } \\
\text { Coal } \\
\text { Coal } \\
\text { Coal }\end{array}$ & $\begin{array}{l}\mathbf{N} \\
\mathbf{N} \\
\mathbf{N} \\
\mathbf{N} \\
\mathbf{N} \\
\mathbf{N}\end{array}$ & $\begin{array}{l}\mathbf{Y}^{\mathbf{h}} \\
\mathbf{Y}^{\mathbf{h}} \\
\mathbf{Y}^{\mathbf{h}} \\
\mathbf{N} \\
\mathbf{Y} \\
\mathbf{Y}^{\mathbf{h}}\end{array}$ & $\begin{array}{l}\text { N/A } \\
\text { N/A } \\
\text { N/A } \\
\text { N/A } \\
\text { Diffuser } \\
\text { N/A }\end{array}$ & $\begin{array}{r}- \\
- \\
- \\
18^{\bar{d}} \\
-\end{array}$ \\
\hline $\begin{array}{l}\text { Pacific Gas \& Electric } \\
\text { (Walton 1993) }\end{array}$ & $\begin{array}{l}\text { Contra Costa } \\
\text { Pittsburg } \\
\text { Potrero } \\
\text { Hunters Point } \\
\text { Humboldt Bay } \\
\text { Moss Landing 1-5 } \\
\text { Moss Landing 6-7 } \\
\text { Morro Bay } \\
\text { Diablo Canyon }\end{array}$ & $\begin{array}{r}1,236 \\
1,302 \\
207 \\
307 \\
105 \\
544 \\
1,478 \\
1,002 \\
2,152\end{array}$ & $\begin{array}{l}\text { Gas/oil } \\
\text { Gas/oil } \\
\text { Gas/oil } \\
\text { Gas/oil } \\
\text { Gas/oil } \\
\text { Gas/oil } \\
\text { Gas/oil } \\
\text { Gas/oil } \\
\text { Nuclear }\end{array}$ & $\begin{array}{l}\mathbf{Y} \\
\mathbf{Y} \\
\mathbf{N} \\
\mathbf{N} \\
\mathbf{N} \\
\mathbf{Y} \\
\mathbf{N} \\
\mathbf{N} \\
\mathbf{N}\end{array}$ & $\begin{array}{l}\mathbf{N} \\
\mathbf{N} \\
\mathbf{Y} \\
\mathbf{Y} \\
\mathbf{Y} \\
\mathbf{N} \\
\mathbf{Y} \\
\mathbf{Y} \\
\mathbf{Y}\end{array}$ & $\begin{array}{l}\text { CT } \\
\text { CT } \\
\text { N/A } \\
\text { N/A } \\
\text { N/A } \\
\text { CT } \\
\text { N/A } \\
\text { N/A } \\
\text { N/A }\end{array}$ & $\begin{array}{r}110^{\mathrm{e}} \\
143^{\mathrm{e}} \\
- \\
- \\
- \\
53^{\mathrm{e}} \\
- \\
- \\
-\end{array}$ \\
\hline $\begin{array}{l}\text { San Diego Gas \& Electric } \\
\text { (Jacobsen 1993) }\end{array}$ & $\begin{array}{l}\text { South Bay } \\
\text { Silver Gate } \\
\text { Encina 1-4 } \\
\text { Encina } 5\end{array}$ & $\begin{array}{l}670 \\
230 \\
608 \\
315\end{array}$ & $\begin{array}{l}\text { Gas/oil } \\
\text { Gas/diesel } \\
\text { Gas/oil } \\
\text { Gas/oil }\end{array}$ & $\begin{array}{l}\mathbf{N} \\
\mathbf{N} \\
\mathbf{N} \\
\mathbf{Y}\end{array}$ & $\begin{array}{l}\mathbf{Y} \\
\mathbf{Y} \\
\mathbf{Y} \\
\mathbf{N}\end{array}$ & $\begin{array}{l}\text { N/A } \\
\text { N/A } \\
\text { N/A } \\
\text { Offshore } \\
\text { pipeline/diffuser }\end{array}$ & $\begin{array}{l}- \\
- \\
\overline{54}\end{array}$ \\
\hline
\end{tabular}

See next page for footnotes. 


\section{TABLE 1 (Cont.)}

a Summary results:
Total MW evaluated
78,049
MW meeting mixing zone
MW needing diffuser
20,085
4,687
Total cost ( $\$$ million)
6,561
MW needing CT
52,769
$\begin{array}{lr}\text { Total for diffusers } & 286 \\ \text { Total for CTs } & 5,359\end{array}$
$\begin{array}{lr}\text { Total for diffusers } & 286 \\ \text { Total for CTs } & \mathbf{5 , 3 5 9}\end{array}$
Total for plant closure $\quad 916$

MW needing plant closure

508

b Information provided by power companies - not specific about whether winter, summer, or nameplate capacity.

c $\mathrm{CT}=$ cooling tower; $\mathrm{N} / \mathrm{A}=$ not applicable.

d Assumes cost rates for retrofitting diffusers of $\$ 43 / \mathrm{kW}$ for fossil-fuel plants and $\$ 59 / \mathrm{kW}$ for nuclear plants and for retrofitting cooling towers of $\$ 108 / \mathrm{kW}$ for fossil-fuel plants and $\$ 201 / \mathrm{kW}$ for nuclear plants.

e Actual estimates provided by power companies and reported in Veil (1993).

f This cost is for replacement capacity since the existing plant would be closed.

E Based on Tennessee Valley Authority's Sequoyah Plant.

h Presently, the state of Wisconsin does not have thermal water quality standards; therefore, all plants are in compliance for a 1,000-foot mixing zone. Wisconsin is currently working on thermal standards; if a standard of $89^{\circ} \mathrm{F}$ maximum temperature were adopted, Wisconsin Electric Power could not meet the standard at the edge of a 1,000-foot mixing zone at this plant. 
The remaining 58 plants, ${ }^{4}$ representing $57,964 \mathrm{MW}$ of capacity ( $74 \%$ of the total capacity reported in this study), would not be able to meet current thermal standards at the edge of a 1,000-foot mixing zone and would have to find an alternative mode of operation. The possible alternatives are discussed in the next chapter.

Although the steam electric power industry is the primary industrial sector that would be affected by a 1,000-foot mixing zone limit, other industries that use large volumes of water for cooling might also be affected. Included are the steel, aluminum, paper, and cement manufacturing industries and waste-to-energy facilities.

4 The 24 plants that could meet a standard based on a 1,000-foot mixing zone and the 58 plants that could not sum to 82 rather than 79 plants. Three of the plants have one set of units that could meet the standard and a different set of units that could not. Those plants were counted in both categories. 


\section{POSSIBLE ALTERNATIVES}

If a generating station with once-through cooling were unable to comply with a 1,000-ft mixing zone limit, the utility would have to select a different operating or compliance alternative. While a variety of alternatives exist, few are universally practical. The following sections discuss several of the possible alternatives.

\subsection{ALTERNATIVES WITH LIMITED APPLICABILITY}

\subsubsection{Seeking Relaxed Thermal Standards}

The least costly alternative generally involves persuading the state regulatory agency to revise the applicable thermal standards. Most of the plants currently meeting a standard based on a 1,000-foot mixing zone are operating under thermal standards that are more lenient than average. In some cases, states may be willing to develop site-specific water quality standards for temperature, but this approach will not be successful in all cases. Antidegradation requirements may preclude relaxation of water quality standards.

\subsubsection{Retiring Plants}

In some cases, the utility might elect to retire the plant. Typically, such plants are very old, and the expense of retrofitting them with thermal control measures cannot be justified. This alternative is drastic and is not expected to be adopted very frequently nationwide.

\subsubsection{Shedding Load}

Although power production is reduced under load shedding, this alternative is less drastic than plant retirement. Under load shedding, the plant produces less power, and the resulting discharge is sufficiently cool to comply with the mixing zone limit. A variation of this practice is seasonal operation. From season to season, the plant operates only at the production level that permits its thermal discharges to meet all applicable requirements. The plant may operate at or near full capacity in the cooler months; however, during the warmer months, operations are curtailed so that the discharges are reduced or discontinued as needed to meet thermal limits. This solution is not expected to be adopted very often because many power companies cannot afford the loss of generated power, especially during the warmer months. 


\subsubsection{Using Cooling Ponds or Lakes}

A power plant cooling system can be retrofitted with man-made cooling ponds or lakes to avoid the need to comply with discharge limits set for natural water bodies. However, such ponds and lakes require large amounts of space. They may be passive or may include spray systems to enhance evaporation. This approach may not be viable for the long term, however, because there has been some suggestion that discharges to man-made, selfcontained cooling ponds should be subject to the same discharge requirements as discharges to navigable waters (Inside EPA 1993). This issue is unresolved.

\subsection{ALTERNATIVES WITH GREATER APPLICABILITY}

Most companies faced with having to comply with a standard based on a 1,000-foot mixing zone would either modify their existing discharge structure to incorporate a diffuser or retrofit cooling towers. These alternatives are discussed below.

\subsubsection{Modifying Discharge Structure}

Some plants may choose to continue using once-through cooling by switching from a surface discharge structure, such as a canal, to a deep-water outfall structure. The outfall pipe would either end in deep water or would employ a high-rate diffuser, or both. In either case, the heated water and ambient water would mix more readily, thereby minimizing the zone of elevated temperature, and the heated water would emerge farther below the surface water layer that supports much of aquatic life. This solution is not always practical because the receiving waters may not be large enough or deep enough for the alteration to make a significant difference.

\subsubsection{Installing Cooling Towers}

Cooling towers represent a more feasible alternative for many plants. In general, most fossil-fuel plants would add mechanical-draft cooling towers, while most nuclear plants would add natural-draft towers. The type actually selected in any given case would depend on a variety of site-specific factors.

Rather than being installed only to replace once-through cooling, cooling towers could also be used in a helper mode to cool a portion of the once-through flow. This type of system could be effective in cases where the once-through discharge temperature is fairly close to the allowable temperature. The Tennessee Valley Authority operates helper cooling towers at several of its power plants and would, as a compliance alternative, convert some helper towers to full closed-cycle towers (Loudermilk 1993).

A third possible cooling tower configuration is a dry cooing tower system, which transfers heat directly to the air without using evaporation of water as the heat transfer mechanism. However, such systems have not yet been used to any great extent in the United 
States (Electric Power Research Institute [EPRI] 1991). Compared with mechanical- and natural-draft systems, dry cooling tower systems generally are far more expensive to construct, require an extremely large amount of power to run, extract a much higher energy penalty, and are noisy. Therefore, they were not considered in this study in estimating the capital cost of complying with the proposed 1,000-foot mixing zone limit. Where water is in short supply, however, dry cooling systems may be used in the future.

\subsection{ALTERNATIVES SELECTED}

As shown in Table 1, operators of the 58 plants that could not meet thermal standards at the edge of a 1,000-foot mixing zone selected primarily two alternatives for compliance - cooling towers and diffusers. Diffusers would be added at 6 plants, ${ }^{5}$ cooling towers at 39 plants, and both diffusers and cooling towers at 8 other plants. At two plants, helper towers would be converted to full closed-cycle cooling. One company said it would consider either cooling towers or spray systems to enhance evaporation at three of its plants (Oliver 1993). One plant would be retired, and new replacement generating capacity would be constructed elsewhere (Bollinger and Bozek 1993). Several companies said that they would first try to have the state regulatory agency relax thermal standards, but they were not optimistic about the success of such requests (Marshall 1993; Oliver 1993). For the cost estimates presented in later chapters, all alternatives involving use of cooling towers have been combined with the one plant that would be retired ${ }^{6}$ into one category ( 52 plants). The six plants using just diffusers constitute a second category.

5 Of the six plants that would add diffusers, three are operated by Commonwealth Edison, which would first try adding diffusers and then add cooling towers if needed (Bollinger and Bozek 1993). For calculating cost estimates in this report, those plants are treated as adding diffusers.

6 Because the cost of retiring a plant and building new generating capacity greatly exceeds the cost of adding a cooling tower $(\$ 1,803 / \mathrm{kW}$ [data from Potomac Electric Power Company, in Bollinger and Bozek 1993] vs. $\$ 108 / \mathrm{kW}$ ), retirement is an unlikely alternative for many plants. By combining this one plant with those plants adding cooling towers, the plant is still counted in the data set, and the final cost estimate becomes somewhat more conservative as a result. 


\section{CAPITAL COSTS TO COMPLY WITH A 1,000-FOOT MIXING ZONE}

The calculation of compliance costs follows the assumption that all plants unable to meet thermal standards at the edge of a 1,000-foot mixing zone would be retrofitted with cooling towers, a diffuser, or both. If both cooling towers and a diffuser are selected, the cost rate used in the calculation is that for just the cooling towers. If cooling towers are selected, the calculations assume that fossil-fuel plants will add mechanical-draft towers and that nuclear plants will add natural-draft towers.

The estimated compliance costs evaluated in this report include two principal components: (1) the capital cost of the selected cooling system alternative and (2) the fuel costs and replacement capacity costs for the increased energy required for the retrofitted system. The capital cost component is discussed in the following sections of this chapter. The additional fuel costs and replacement capacity costs for a retrofitted plant result from the increased energy required to operate cooling towers and diffusers (compared with operation of a regular once-through cooling system). This cost component is discussed in Chapter 5.

Other factors that could add to compliance costs, but that are not included in the cost estimates in this report, are the operations and maintenance (O\&M) costs for the retrofitted system and any necessary land acquisition and facilities relocation costs. Stone \& Webster (1992) estimates that annual $0 \& M$ costs are about $0.7 \%$ of the capital cost of retrofitting cooling towers. No data are available for diffuser O\&M costs, but it is believed that those costs are comparably low. Consequently, O\&M costs are not included in the estimate of compliance costs given in this report.

At some power plant sites, sufficient land is not available for adding large components such as cooling towers. The power company would have to acquire additional land or relocate existing facilities at the site to make room for the new components. These costs are very site-specific, but at certain facilities they could be quite large. Because of the great variability of this cost component, it is not included in the estimate of compliance costs.

\subsection{ELEMIENTS OF A CAPITAL COST ESTIMATE}

Capital costs tend to be very site-specific, and estimates must be based on plant configuration, distance from plant to receiving waters, characteristics of the receiving water, and climate. Therefore, a site-specific estimate will include a variety of costs beyond the cost of the selected device itself. The site-specific estimate would include the costs for the following activities:

- Conducting engineering surveys and preparing the site; 
- Demolishing or closing intake structure and cooling system components that are no longer needed and constructing any new intake structures or components needed;

- Obtaining federal, state, and local permits and preparing environmental impact documents;

- Replacing piping, valves, pumps, and condenser to meet the higher pressure requirements of an alternative system;

- Supplying new electrical service;

- Replacing power lost when the plant is shut down for retrofitting activities beyond the routine maintenance outage period; and

- Constructing water treatment facilities for the recirculating water if cooling towers are added.

\subsection{COST RATES}

\subsubsection{Cooling Towers}

In a study involving 38 plants owned by 14 power companies, Veil (1993) estimated that the capital cost to retrofit cooling towers ranged from $\$ 105$ to $\$ 108 / \mathrm{kW}$ for fossil-fuel plants and from $\$ 171$ to $\$ 201 / \mathrm{kW}$ for nuclear plants (1992 dollars). These estimates compare reasonably well with those calculated by Stone \& Webster (1992) for the Edison Electric Institute -- $\$ 130 / \mathrm{kW}$ for fossil-fuel plants and $\$ 230 / \mathrm{kW}$ for nuclear plants. In the present study, the upper ends of the ranges from Veil (1993) have been selected as the cooling tower capital cost rates for estimating total national compliance costs.

\subsubsection{Diffusers}

An extensive literature search revealed no recent comparative study of diffuser cost rates. The only reference identified that estimated capital costs for power industry diffusers was a 1978 report prepared by National Economic Research Associates, Inc. (NERA) and Stone \& Webster. Capital cost rates presented in that report for both diffusers and cooling towers are shown in Table 2. The cost rates were originally provided in 1977 dollars and have been escalated to 1992 dollars by using the Construction Cost Index (Engineering News Record 1992). Even with this degree of escalation, however, the cost rates for cooling towers 
TABLE 2 Capital Cost Rates to Retrofit Various Types of Cooling Systems, Based on Data from NERA and Stone \& Webster (1978)

\begin{tabular}{ccccccc}
\hline & \multicolumn{2}{c}{ Cooling } & Fossil-Fuel Plants & & \multicolumn{2}{c}{ Nuclear Plants } \\
\cline { 2 - 3 } \cline { 5 - 6 } System Type & $1977 \$ / \mathrm{kW}$ & $1992 \$ / \mathrm{kW}$ & & $1977 \$ / \mathrm{kW}$ & $1992 \$ / \mathrm{kW}$ \\
\hline Offshore diffuser & 10.6 & 20.1 & & 15.6 & 29.2 \\
$\begin{array}{c}\text { Mechanical-draft } \\
\text { cooling tower }\end{array}$ & 26.4 & 50.0 & & 38.8 & 73.5 \\
$\begin{array}{c}\text { Natural-draft } \\
\text { cooling tower }\end{array}$ & 35.8 & 67.8 & & 52.6 & 99.7 \\
\hline
\end{tabular}

are less than half of the comparable cost rates estimated by Veil (1993). Therefore, to maintain consistency, the NERA and Stone \& Webster (1978) cost rates for diffusers have been multiplied by the ratio of Veil (1993) cost rates for cooling towers to NERA and Stone \& Webster (NERA-S\&W) cost rates for cooling towers:

1. Calculate ratio for mechanical-draft towers (fossil-fuel plant):

Veil/NERA-S\&W $=108 / 50.0=2.16$

2. Calculate ratio for natural-draft towers (nuclear plant):

Veil/NERA-S\&W $=201 / 99.7=2.02$

3. Multiply NERA-S\&W cost rates for diffusers by calculated ratios:

$$
\begin{aligned}
& \text { Fossil-fuel }=20.1 \times 2.16=\$ 43 / \mathrm{kW} \\
& \text { Nuclear }=29.2 \times 2.02=\$ 59 / \mathrm{kW}
\end{aligned}
$$

\subsection{CALCULATION OF NATIONWIDE COST ESTIMATE}

To estimate the nationwide capital cost of retrofitting cooling towers or diffusers at all plants that could not meet thermal standards at the edge of a 1,000-foot mixing zone, the affected megawatts of capacity are multiplied by the cost rates presented in this chapter. Although Table 1 lists an estimated cost for each plant to retrofit a selected alternative, the majority of those values are not independent estimates provided by the power company solely for this study. Many of the estimates were derived by multiplying the megawatt generating capacity of the plant by literature-based cost rates (as indicated in Table 1 by footnote "d"). For most of the other plants, the costs listed in Table 1 are estimates provided by power companies to the author and reported in Veil (1993). Since Veil (1993) serves as the basis 
for the cooling tower cost rates used in this report, and most of the other power-companysupplied data had previously been used by Veil to calculate the 1993 cooling tower cost rates, the costs reported in Table 1 are not truly independent estimates and are shown in Table 1 for informational purposes only. The approach used in this report is to apply a consistent cost rate to all affected capacity.

As reported in Chapter 2, plants with about 250,466 MW of generating capacity use once-through cooling. Fossil-fuel plants account for $213,700 \mathrm{MW}(85 \%)$ of this capacity, and nuclear plants make up 36,766 MW (15\%). Table 1 shows which alternative would be selected to meet thermal standards at the edge of a 1,000-foot mixing zone for each of the affected plants in the sample data. The cost estimation methodology used in this report assumes that the same pattern of alternative selection found in the sample data would apply on a nationwide basis.

To simplify calculations, all sample data alternatives involving retrofitting with cooling towers (adding cooling towers or a spray system, converting helper towers to full-time closed-cycle cooling, or adding cooling towers and diffusers) and the one plant that would be retired have been combined into a single class. This class includes $53,277 \mathrm{MW}$ of generating capacity ( $68 \%$ of the total $78,049 \mathrm{MW}$ of capacity included in the sample). If this class were to proportionately follow the national distribution of capacity using once-through cooling ( $85 \%$ fossil-fuel and $15 \%$ nuclear), fossil-fuel plants with $58 \%$ of the total capacity and nuclear plants with $10 \%$ of the total capacity would be retrofitted with cooling towers. A second class of plants representing $4,687 \mathrm{MW}$ (6\% of total capacity in the sample - 5\% fossil-fuel, $1 \%$ nuclear) would add diffusers to existing once-through cooling systems. Plants with the remaining $20,085 \mathrm{MW}$ of capacity (27\% of total) can already meet a standard based on a 1,000 -foot mixing zone and would therefore incur no new capital costs.

Table 3 shows the selected alternatives, the percentage of capacity (based on the sample data for this study) anticipated to choose each alternative, the estimated capacity (in megawatts) nationwide that would choose each alternative, the cost rates, and the total capital costs. The total estimated national capital cost for retrofitting plants that cannot meet thermal standards at the edge of a 1,000 -foot mixing zone is $\$ 21.4$ billion. 
TABLE 3 Calculation of Nationwide Capital Cost Estimate

\begin{tabular}{|c|c|c|c|c|}
\hline Selected Alternative & $\begin{array}{c}\text { Percentage } \\
\text { of Capacity } \\
\text { Choosing } \\
\text { Alternative }^{\mathrm{a}}\end{array}$ & $\begin{array}{c}\text { Affected } \\
\text { Capacity } \\
\text { Choosing } \\
\text { Alternative } \\
\text { (MW) }\end{array}$ & $\begin{array}{c}\text { Cost } \\
\text { Rate } \\
(\$ / \mathrm{kW})\end{array}$ & $\begin{array}{l}\text { Total Cost } \\
\text { (million } \$ \text { ) }\end{array}$ \\
\hline \multicolumn{5}{|l|}{ Diffuser } \\
\hline Fossil-fuel plants & 5 & 12,523 & 43 & 538 \\
\hline Nuclear plants & 1 & 2,504 & 59 & 148 \\
\hline \multicolumn{5}{|l|}{ Cooling towers } \\
\hline $\begin{array}{l}\text { Fossil-fuel plants } \\
\text { (mechanical-draft towers) }\end{array}$ & 58 & 145,270 & 108 & 15,690 \\
\hline $\begin{array}{l}\text { Nuclear plants } \\
\text { (natural-draft towers) }\end{array}$ & 10 & 25,047 & 201 & 5,034 \\
\hline No changes needed & 26 & 65,121 & $\mathbf{N} / \mathbf{A}^{\mathbf{b}}$ & 0 \\
\hline Total & 100 & 250,466 & N/A & 21,410 \\
\hline
\end{tabular}

a Based on sample data summarized in Table 1.

b $\mathrm{N} / \mathrm{A}=$ not applicable. 


\section{ADDITIONAL ENERGY COSTS TO COMPLY WITH A 1,000-FOOT MIXING ZONE}

\subsection{DESCRIPTION OF THE ENERGY PENALTY}

The second cost component considered in this report is the "energy penalty" associated with retrofitting a plant with a cooling tower or a diffuser. If a power plant switches from a once-through cooling system to a cooling tower, the net output of electricity from the plant will be reduced. The reduction occurs for two main reasons. First, with the use of cooling towers, the turbine back pressure increases, resulting in less efficient generation than with regular once-through cooling. Steam condensers are designed to produce a vacuum at the outlet end of the turbine (that is, to have a low back pressure), and the more complete the vacuum, the greater the generating efficiency. When the temperature of the cooling water increases, a poorer vacuum is created, and less energy can be extracted. Recirculating water from a cooling tower has a higher temperature, on an annual average, than once-through cooling water. Therefore, after switching from once-through cooling to cooling towers, a plant generates less energy from the same amount of fuel.

The second reason for the energy penalty associated with a cooling tower is the additional power required to operate the retrofitted cooling system. Although a once-through system pumps a large volume of water, the pumping head (the elevation to which the water must be pumped plus frictional losses) is relatively low. A cooling tower uses a smaller volume of water, but that water is pumped at a higher pressure and to a higher elevation. Consequently, power requirements are substantially greater for a cooling tower than for a once-through system. In the case of a natural-draft cooling tower, the pump head may be more than 90 feet. For a mechanical-draft cooling tower, the head typically is much lower, but the total energy needed to operate this type of tower is higher because additional energy is required to power the fans. The water treatment system used for recirculated water also requires electricity to operate chemical mixers and pumps. Still more electricity is needed to heat, cool, and light the additional buildings associated with the recirculating water system.

Diffusers also cause an increase in pump head by directing the discharge flow through a series of small-diameter nozzles at high velocity rather than through a large pipe opening at lower velocity. This increased pump head results in increased pumping, which in turn creates additional energy requirements.

Power companies have several options relative to the energy penalty. They can operate the plant at lower net power output, or, in some cases, they can run it more frequently or at a higher temperature. The latter option requires that additional fuel be burned to maintain output. In either case, there is an energy cost associated with the retrofitting of cooling towers. 


\subsection{MAGNITUDE OF THE ENERGY PENALTY}

Veil et al. (1993) reviewed literature values and generated an independent estimate of the energy penalty for cooling towers. The authors concluded that for fossil-fuel plants, the energy penalty ranges from 1.1 to $4.6 \%$ of capacity, with most of the data falling in the range of 1.5 to $2.5 \%$. The energy penalty for nuclear plants ranges from 1.0 to $5.8 \%$ of capacity, with the most relevant data falling in the range of 2 to $3 \%$. In this report, the smaller values of the estimated ranges are used for each type of plant.

The report by NERA and Stone \& Webster (1978) indicates that diffusers retrofitted at fossil-fuel plants result in a $0.2 \%$ energy penalty, and diffusers retrofitted at nuclear plants result in a $0.28 \%$ energy penalty. The energy penalty values reported for cooling towers in NERA and Stone \& Webster (1978) fall within the ranges considered by Veil et al. (1993), so no corrections such as those described in Chapter 4 have been made here.

\subsection{REPLACEMENT ENERGY COSTS}

\subsubsection{Cost of Generating Replacement Energy}

The cost of compensating for the energy penalty has two components - the cost of generating replacement energy and the capital cost of building new generating rapacity. Replacement energy would likely be provided from sources throughout each affected power pool or utility system. The contributions would be provided in small increments from the most economical generating units that were available for additional dispatching. VanKuiken et al. (1992) developed replacement energy costs for each of 112 nuclear reactors located in 20 of the 26 power pools ${ }^{7}$ that constitute the U.S. electrical utility grid. The 20 power pools provide more than adequate coverage for developing cost estimates representative of U.S. averages. Veil et al. (1993), using data from VanKuiken et al. (1992), estimated a weighted average cost (in 1991 dollars) for replacement power of 28.3 mills $8 / \mathrm{kWh}$. Converted to 1992 dollars by use of the Construction Cost Index, the value is $29.0 \mathrm{mills} / \mathrm{kWh}$.

The total energy to be replaced can be estimated by applying historical capacity factors and energy penalties to the megawatts of capacity affected by the 1,000-foot mixing zone limit. Table 4 shows the estimates of replacement energy needed for each selected alternative. The total nationwide replacement energy needed is estimated to be between 12.7 and 20.6 billion $\mathrm{kWh}$ per year.

7 Power pools represent groups of utility systems that participate in coordinated operations, either through centrally dispatched control systems or through less formal economic capacity and energy exchanges.

8 A mill is 0.1 cent. 
TABLE 4 Nationwide Replacement Energy and Capacity Needed to Compensate for the Energy Penalty Associated with Compliance Alternatives

\begin{tabular}{|c|c|c|c|c|c|}
\hline Selected Alternative & $\begin{array}{c}\text { Affected } \\
\text { Capacity } \\
\text { Choosing } \\
\text { Alternative } \\
\text { (MW) }\end{array}$ & $\begin{array}{c}\text { Annual } \\
\text { Capacity } \\
\text { Factor } \\
(\%)\end{array}$ & $\begin{array}{c}\text { Energy } \\
\text { Penalty } \\
(\%)\end{array}$ & $\begin{array}{c}\text { Replacement } \\
\text { Energy } \\
\text { Needed } \\
\text { (billion } \\
\text { kWh/year) }\end{array}$ & $\begin{array}{l}\text { Replacement } \\
\text { Capacity } \\
\text { Needed } \\
\text { (MW) }\end{array}$ \\
\hline \multicolumn{6}{|l|}{ Diffusers } \\
\hline Fossil-fuel plants & 12,523 & 50.7 & 0.2 & 0.1 & 25 \\
\hline Nuclear plants & 2,504 & 66.3 & 0.28 & 0.04 & 7 \\
\hline \multicolumn{6}{|l|}{ Cooling towers } \\
\hline $\begin{array}{l}\text { Fossil-fuel plants } \\
\text { (mechanical-draft towers) }\end{array}$ & 145,270 & 50.7 & $1.5-2.5$ & $9.7-16.1$ & $2,180-3,630$ \\
\hline $\begin{array}{l}\text { Nuclear plants } \\
\quad \text { (natural-draft towers) }\end{array}$ & 25,047 & 66.3 & $2.0-3.0$ & $2.9-4.4$ & $500-750$ \\
\hline National total & & & & $12.7-20.6$ & $\approx 2,700-4,400$ \\
\hline
\end{tabular}

The nationwide cost of generating the energy needed to compensate for the energy penalty is estimated by multiplying the weighted average cost for replacement energy by the total replacement capacity needed. This total cost is estimated to be $\$ 370-\$ 590$ million per year. Over 20 years, the levelized value of these costs would be about $\$ 500-\$ 810$ million per year ( $\$ 10-\$ 16.2$ billion total). These estimates assume zero real escalation in fuel and variable O\&M costs, a discount rate of $10.5 \%$, and an annual inflation rate of $4 \%$.

\subsubsection{Capital Cost of Building New Generating Capacity}

The second component of the energy penalty cost is the capital cost of building new generating capacity. The nationwide amount of replacement capacity needed is estimated to range from 2,700 to 4,400 MW (Table 4). Responses to the projected efficiency losses by utilities in the United States would probably span the entire range of capacity options. Each utility would base its decision on existing reserve margins, construction schedules for planned facilities, fuel prices, load projections, and the availability of power purchases from interconnected systems. To simplify these issues, Veil et al. (1993) suggested a range of replacement capacity costs. At the low end of this range is the cost for a 50-MW combustion turbine unit - approximately $\$ 450 / \mathrm{kW}$. At the high end is the cost for upgrading a 500-MW coal unit to $600 \mathrm{MW}$ - approximately $\$ 1,080 /$ incremental $\mathrm{kW}$ (EPRI 1988, 1989). Application of the cost range of $\$ 450-\$ 1,080 / \mathrm{kW}$ to the range of total capacity needs $(2,700$ $4,400 \mathrm{MW}$ ) yields estimated nationwide replacement capacity costs of $\$ 1.2-\$ 4.8$ billion. 


\section{ENVIRONMENTAL IMPACTS OF RETROFITTING COOLING TOWERS AND DIFFUSERS}

\subsection{INCREASED POWER GENERATION}

As discussed in Chapter 5, conversion from once-through cooling systems to cooling towers and diffusers exacts an energy penalty. To fulfill these additional energy demands, a power company must generate more electricity by burning more fuel. Neither the process of extracting the fuel from the environment nor transporting it to the power plant site is environmentally benign. These impacts cannot be easily quantified, but clearly they are deleterious to the environment.

Each unit of fossil fuel burned would cause additional air pollutant emissions. In light of current concerns about global warming, carbon dioxide emissions are of interest. U.S. Department of Energy (DOE) staff computed the additional carbon dioxide releases and evaporative losses that could occur if all power plants that currently use once-through cooling were converted to cooling towers (Carter 1991). That analysis assumed only a $1 \%$ energy penalty, but still resulted in an estimated increase in carbon dioxide emissions of 11.2 million tons per year and estimated increased evaporative losses of 3.6 million gallons of water per minute.

However, not all power plants that currently use once-through cooling systems would convert to cooling towers to comply with a 1,000-foot mixing zone standard. Some of the plants would select diffusers rather than cooling towers, and some would not need to make any changes to meet the mixing zone limit. Therefore, Carter's estimate must be reduced accordingly. Since the plants that would install diffusers represent only $5 \%$ of the cases and since the $1 \%$ energy penalty value used in Carter's calculations is already very conservative, the number of plants retrofitting diffusers is combined with the number of plants retrofitting cooling towers for evaluation of impacts. About $26 \%$ of the planits using once-through cooling would not need to make any changes to meet the 1,000-foot mixing zone standard. Therefore, Carter's estimates must be reduced by $26 \%$, resulting in an estimated increase in carbon dioxide emissions of about $\mathbf{8 . 3}$ million tons per year and increases in evaporative losses of about 2.7 million gallons of water per minute.

The increased air pollutant emissions and evaporative water losses would not be the only impacts resulting from the need to increase power production. Many power companies would not be able to supply the additional power with their existing generating capacity, so they would have to build new capacity. Environmental impacts, such as storm-water runoff, are associated with any construction project, and features of site development (such as service roads, parking lots, and pipeline and power line corridors) would result in changes in land use, runoff characteristics, and wildlife habitat. Finally, generation of additional power would increase production of solid wastes. 


\subsection{INCREASED WATER CONSUMPTION}

Another impact from installing a large number of new cooling towers would be increased water consumption. Cooling towers rely primarily on evaporation to achieve their cooling. Once-through cooling systems also cause evaporation by raising the temperature of the thermal plume in the receiving waters. However, little quantitative evidence exists regarding the magnitude of the once-through evaporative effect because it is widely dispersed and gradual.

When Carter's data are adjusted for those once-through-cooling plants that already meet a 1,000-foot mixing zone standard, as discussed above, the increased evaporative losses from the once-through plants that would require installation of cooling towers can be estimated at 2.7 million gallons of water per minute. For comparison, the average flow of the Potomac River near Washington, D.C., is about 5.1 million gallons per minute.

In some parts of the country, additional evaporative losses would place a strain on already limited water resources. In California and several other western states, drought conditions have continued for several years. Even the eastern states, where water has traditionally been plentiful, have experienced temporary drought conditions, and it is now generally recognized that water is not a limitless commodity. Efforts to reduce aquatic thermal impacts by limiting mixing zones to 1,000 feet might be counterproductive. Increased water consumption through cooling tower evaporation could reduce the volume of water in the stream available for dilution of heated effluent and reduce the extent of viable aquatic habitat adjacent to or downstream from the plant. Other recreational or water supply uses of the receiving water could also be impaired by a requirement that forced utilities to retrofit cooling towers. 


\section{FINDINGS AND CONCLUSIONS}

This report evaluates the cost to the steam electric power industry of restriction of thermal mixing zones for power plants with once-through cooling to 1,000 feet from the discharge point. The findings and conclusions are presented below.

\subsection{FINDINGS}

- Most states have water quality standards for the temperature that must not be exceeded outside of designated mixing zones. The methods and criteria used to determine the size and shape of allowable mixing zones differ from state to state.

- A major legislative proposal introduced in May 1991 to reauthorize the CWA, S. 1081, proposed elimination of Section 316(a) variances and restriction of mixing zones to 1,000 feet. This legislation was not passed; the most current Senate CWA reauthorization bill, S. 1114 (103rd Congress), does not include either of these provisions. It remains unclear how Congress intends to deal with thermal issues in a reauthorized CWA, so data collected on the impacts of the proposals in S. 1081 (i.e., a 1,000-foot mixing zone limit and deletion of the Section 316(a) variance provision) are analyzed here.

- On the basis of data collected for 79 plants representing 13 companies in different parts of the country, $74 \%$ of the plants currently using oncethrough cooling systems could not meet existing thermal standards at the edge of a 1,000 -foot mixing zone. Of this total, $68 \%$ would retrofit cooling towers, and $6 \%$ would retrofit diffusers.

- The estimated capital costs of retrofitting cooling towers are based on literature values of $\$ 108 / \mathrm{kW}$ for fossil-fuel plants and $\$ 201 / \mathrm{kW}$ for nuclear plants. Estimated capital costs for diffusers are based on literature values that have been scaled up to reflect more current conditions. They are $\$ 43 / \mathrm{kW}$ for fossil-fuel plants and $\$ 59 / \mathrm{kW}$ for nuclear plants.

- In 1991 , power plants with a total generating capacity of 250,466 MW used once-through cooling. Fossil-fuel plants accounted for $213,700 \mathrm{MW}$ (85\%) of this capacity and nuclear plants made up $36,766 \mathrm{MW}$ (15\%).

- The total estimated nationwide capital cost for retrofitting plants that cannot meet thermal standards at the edge of a 1,000-foot mixing zone, assuming no Section 316(a) variances are available, is $\$ 21.4$ billion. 
- Retrofitting a plant with cooling towers will result in a lower energy output from that plant because of increased turbine back pressure and increased auxiliary power demands. Diffusers also cause an increase in power demand because of an increase in pump head. This differential energy output is known as the energy penalty.

- On the basis of literature estimates, cooling towers result in an energy penalty for fossil-fuel plants that ranges from 1.1 to $4.6 \%$ of capacity, with most of the data falling in the range of 1.5 to $2.5 \%$. The cooling tower energy penalty for nuclear plants ranges from 1.0 to $5.8 \%$, with the most relevant data falling in the range of 2 to $3 \%$. The energy penalty from diffusers is $0.02 \%$ for fossil-fuel plants and $0.028 \%$ for nuclear plants.

- Any power company faced with a cooling tower retrofit would have to make up the energy lost as a result of the energy penalty. If the smaller ranges described for the energy penalty are used, an estimated 12.7 to 20.6 billion $\mathrm{kWh}$ would have to be replaced annually.

- For an average replacement cost of $29.0 \mathrm{mills} / \mathrm{kWh}$, the estimated nationwide cost of replacement generation ranges from $\$ 370$ to $\$ 590$ million per year. Over a 20 -year period, the estimated cost is $\$ 10$ to $\$ 16.2$ billion, assuming zero real escalation in fuel and variable $O \& M$ costs, a discount rate of $10.5 \%$, and an annual inflation rate of $4 \%$. (All values are in 1992 dollars.)

- In addition to paying the fuel costs for providing the extra energy, some power companies would have to construct new generating capacity. Estimates of the nationwide cost for this additional capacity range from $\$ 1.2$ to $\$ 4.8$ billion in 1992 dollars.

- The total nationwide cost (in 1992 dollars) of restricting thermal mixing zones to 1,000 feet (excluding O\&M costs, which are assumed to be small) is estimated to be $\$ 22.6$ to $\$ 26.2$ billion in capital costs and $\$ 10$ to $\$ 16.2$ billion in additional energy generation costs over a 20 -year period.

- The need to generate additional power would increase carbon dioxide emissions by an estimated 8.3 million tons per year. Construction of new generating units would also cause other environmental impacts, such as changes in land use, runoff characteristics, and wildlife habitat and increased production of solid wastes.

- Conversion from once-through cooling systems to cooling towers would result in increased evaporation of about 2.7 million gallons of water per minute. 


\subsection{CONCLUSIONS}

- The cost and environmental impact estimates in this report are based only on plants currently using once-through cooling systems. At least a few plants already using cooling towers would not be able to meet a standard based on a 1,000-foot mixing zone for their cooling tower blowdown discharges. These plants would be required to make additional modifications to their cooling systems.

- Many other industries, including the steel, aluminum, paper, and cement manufacturing industries and waste-to-energy facilities, may also be affected by a thermal mixing zone limit of 1,000 feet. The economic impact from a 1,000-foot mixing zone limit for nonthermal pollutants is not addressed in this report, but it could be very high for many industrial categories, including the power industry.

- Any attempt to place statutory restrictions on thermal mixing zones is likely to result in a very large cost to the power industry and perhaps to other industries as well. Policymakers should give careful consideration to these costs, in addition to the increased air pollutant emissions, solid wastes, and water evaporation attributable to cooling towers and diffusers, before adopting national thermal mixing zone restrictions of any sort. In some parts of the country, the available supplies of water are already so restricted that additional evaporative losses from use of cooling towers could not be tolerated.

- The potential benefits of a 1,000-foot mixing zone have not been widely discussed. Unless the potential benefits are believed to be commensurate with the large cost, little justification exists for limiting thermal mixing zones to 1,000 feet from the point of discharge. 


\section{REFERENCES}

Bollinger, M.F., and C.R. Bozek, 1993, letter from Bollinger (Utility Water Act Group, Washington, D.C.) and Bozek (Edison Electric Institute, Washington, D.C.) to J. Veil (Argonne National Laboratory, Washington, D.C.), Dec. 9.

Carter, D., 1991, memorandum from Carter (U.S. Department of Energy, Washington, D.C.) to J. Gardner (Edison Electric Institute, Washington, D.C.), Sept. 27.

DeHart, R.E., Jr., 1993, letter from DeHart (New England Power, Westboro, Mass.) to J. Veil (Argonne National Laboratory, Washington, D.C.), May 25.

Edison Electric Institute, 1993, Power Statistics Database, maintained by the Utility Data Institute, Washington, D.C., for Edison Electric Institute, Washington, D.C.; accessed by D. Carter, U.S. Department of Energy, Washington, D.C., Sept. 20.

Engineering News Record, 1992, "Construction Cost Index," McGraw-Hill, New York, N.Y., p. 43, March 30.

Electric Power Research Institute, 1988, An Evaluation of Integrated-Gasification-CombinedCycle and Pulverized-Coal-Fired Steam Plants, EPRI AP-5950, Palo Alto, Calif.

Electric Power Research Institute, 1989, TAG Technical Assessment Guide, Electrical Supply - 1989, EPRI P-6587-L, Vol. 1, Rev. 6, Palo Alto, Calif.

Electric Power Research Institute, 1991, Dry Cooling: Perspectives on Future Needs, EPRI GS-7446, Palo Alto, Calif.

Gaulke, A.E., 1993, letter from Gaulke (American Electric Power Service Corp., Columbus, Ohio) to J. Veil (Argonne National Laboratory, Washington, D.C.), April 29.

Inside EPA, 1993, "EPA Water Office Recommends Utility Ponds Be Subject to CWA," Inside Washington Publishers, Washington, D.C., p. 1, Aug. 13.

Jacobsen, F.J., 1993, letter from Jacobsen (San Diego Gas and Electric Co., San Diego, Calif. to J. Veil (Argonne National Laboratory, Washington, D.C.), April 29.

Kunkel, K, 1993, letter from Kunkel (GPU Nuclear Corp., Reading, Pa.) to J. Veil (Argonne National Laboratory), Washington, D.C.), June 7.

Loos, J., 1993, letter from Loos (Potomac Electric Power Co., Washington, D.C.) to J. Veil (Argonne National Laboratory, Washington, D.C.), April 27.

Loudermilk, A.H., 1993, letter from Loudermilk (Tennessee Valley Authority, Knoxville, Tenn.) to J. Veil (Argonne National Laboratory, Washington, D.C.), June 2. 
Marshall, B.M., 1993, letter from Marshall (Virginia Power, Glen Allen, Va.) to J. Veil (Argonne National Laboratory, Washington, D.C.), May 4.

Michaud, D.T., 1993, letter from Michaud (Wisconsin Electric Power Co.) to J. Veil (Argonne National Laboratory, Washington, D.C.), May 17.

National Economic Research Associates and Stone \& Webster, 1978, Thermal Control Cost Factors, prepared for the Utility Water Act Group by National Economic Research Associates, Inc., and Stone \& Webster Engineering Corp., June.

Nispel, D.J., 1993, letter from Nispel (PSI Energy, Plainfield, Ind.) to J. Veil (Argonne National Laboratory, Washington, D.C.), April 22.

Oliver, G.J., 1993, letter from Oliver (Carolina Power \& Light Co., Raleigh, N.C.) to J. Veil (Argonne National Laboratory, Washington, D.C.), April 29.

Smith, J.P., 1993, letter from Smith (Commonwealth Edison, Chicago, Ill.) to J. Veil (Argonne National Laboratory, Washington, D.C.), April 26.

Stone \& Webster, 1992, Evaluation of the Potential Costs and Environmental Impacts of Retrofitting Cooling Towers on Existing Steam Electric Power Plants that Have Obtained Variances under Section 316(a) of the Clean Water Act, prepared for Edison Electric Institute, Washington, D.C.

U.S. Environmental Protection Agency, 1990, "Steam Electric Power Generating Point Source Category," Code of Federal Regulations, Title 40, Part 423, pp. 727-736.

U.S. Senate, 1991a, "Water Pollution Prevention and Control Act of 1991," S. 1081, 102nd Congress, 1st Session, Washington, D.C., May.

U.S. Senate, 1991b, "Water Pollution Prevention and Control Act of 1991," S. 1081, 102nd Congress, 1st Session, Majority Staff Draft, Washington, D.C., Dec. 31.

U.S. Senate, 1993, "Water Pollution Prevention and Control Act of 1993," S. 1114, 103rd Congress, 1st Session, Washington, D.C., May.

U.S. Senate, 1994, "Water Pollution Prevention and Control Act of 1994," S.114, 103rd Congress, 2nd Session, Washington, D.C., Feb. 27.

VanKuiken, J.C., et al., 1992, Replacement Energy Costs for Nuclear Electricity-Generating Units in the United States: 1992-1996, NUREG/CR-4012 (ANL/AA-30), Vol. 3, prepared by Argonne National Laboratory, Argonne, Ill., for U.S. Nuclear Regulatory Commission, Washington, D.C., Sept.

Veil, J.A., 1993, Impact on the Steam Electric Power Industry of Deleting Section 316(a) of the Clean Water Act: Capital Costs, ANL/EAIS-4, Argonne National Laboratory, Argonne, Ill., Jan. 
Veil, J.A., et al., 1993, Impact on the Steam Electric Power Industry of Deleting Section 316(a) of the Clean Water Act: Energy and Environmental Impacts, ANL/EAIS-5, Argonne National Laboratory, Argonne, Ill., Jan.

Walton, C.P., 1993, letter from Walton (Pacific Gas and Electric Co., San Francisco, Calif.) to J. Veil (Argonne National Laboratory, Washington, D.C.), May 11.

Wieland, M.J., 1993, letter from Wieland (Baltimore Gas and Electric Co., Baltimore, Md.) to J. Veil (Argonne National Laboratory, Washington, D.C.), May 7. 

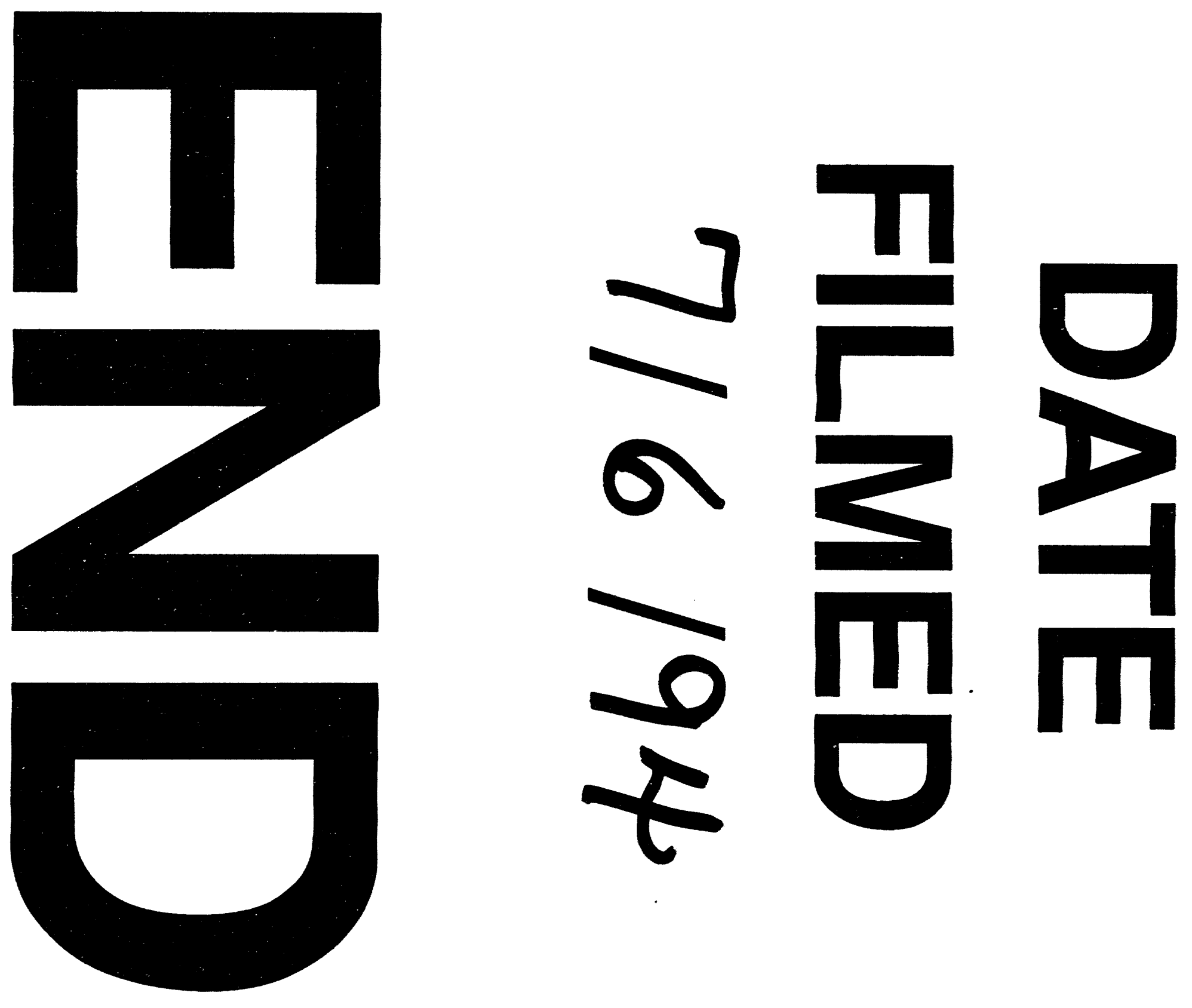
